MAJOR REVIEW

\title{
Wound Healing in Glaucoma Filtering Surgery
}

\author{
GREGORY L. SKUTA, M.D. ${ }^{1,2}$ AND RICHARD K. PARRISH II, M.D. ${ }^{2}$
}

\begin{abstract}
${ }^{\prime}$ Department of Ophthalmology, W. K. Kellogg Eye Center,Universily of Michigan School of Medicine, Ann Arbor, Michigan, and ${ }^{2}$ Bascom Palmer Eye Institute, University of Miami School of Medicine, Miami, Florida
\end{abstract}

\begin{abstract}
Successful glaucoma filtering surgery is characterized by the passage of aqueous humor from the anterior chamber to the subconjunctival space, which results in the formation of a filtering bleb. Aqueous in the subconjunctival space may then exit by multiple pathways. Bleb failure most often results from fibroblast proliferation and subconjunctival fibrosis. Factors associated with an increased risk of bleb failure include youth, aphakia, active anterior segment neovascularization, inflammation, previously failed glaucoma filtering surgery, and, possibly, race. Several surgical and pharmacologic techniques have recently been introduced to enhance success in eyes with poor surgical prognoses. To elucidate the scientific rationale of these methods, we summarize the process of wound healing after glaucoma filtering surgery and describe postoperative clinical and histopathologic features, factors which may affect success, and specific methods to improve surgical success. (Surv Ophthalmol 32:149-170, 1987)
\end{abstract}

Key words. bleb formation - fibroblast proliferation - filtering surgery glaucoma - trabeculectomy - wound healing

Since de Wecker first described the "filtering cicatrix" as a surgical treatment for glaucoma in $1882,{ }^{35}$ many different filtering procedures have been performed to establish a fistula between the anterior chamber and the subconjunctival space. Currently, trabeculectomy is the most popular filtering procedure; ${ }^{85}$ however, full-thickness procedures such as posterior lip sclerectomies, thermosclerostomies, and trephinations are still advocated for some glaucoma patients. ${ }^{164}$

Glaucoma filtering surgery (GFS) differs from most surgical procedures in that inhibition of wound healing is desirable to achieve surgical success. In recent years, several surgical and pharmacologic techniques have been introduced to enhance GFS success. In this review, we will summarize wound healing after GFS and describe postoperative clinical and histopathologic features, factors affecting GFS success, and specific methods to improve surgical success.

\section{Clinical and Histopathologic Findings After Glaucoma Filtering Surgery}

\section{A. BLEB FORMATION, FAILURE, AND ENCAPSULATION}

Successful GFS is generally characterized by formation of a filtering bleb, which is a subconjunctival accumulation of aqueous. Functioning blebs may be thin and polycystic (Fig. 1) with transconjunctival flow of fluid ${ }^{88}$ Other flatter, thicker, and more diffuse blebs with a relatively avascular appearance in comparison to the surrounding conjunctiva (Fig. 2) may also successfully lower intraocular pressure. Kronfeld classified the former as a Type I bleb and 


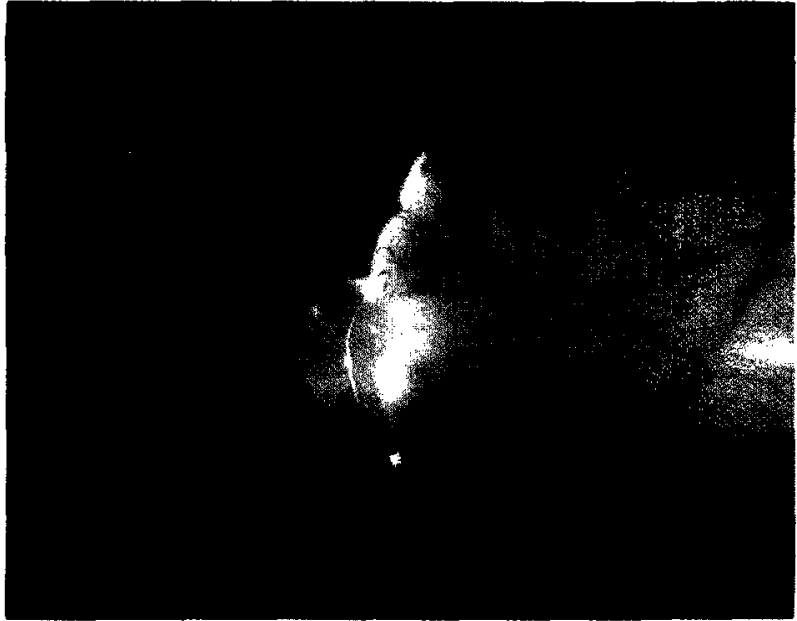

Fig. 1. Thin, polycystic bleb following glaucoma filtering surgery.

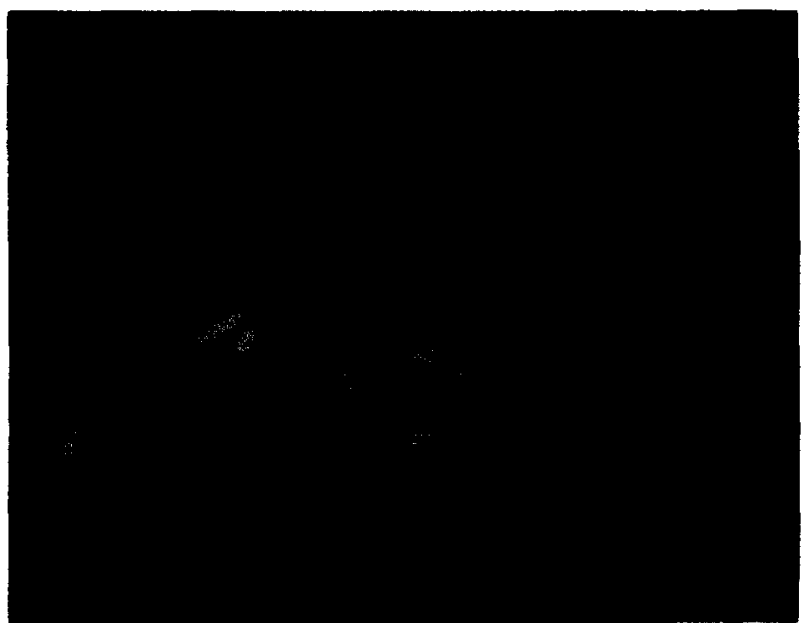

Fig. 3. Failed bleb (owl monkey eye) in which conjunctiva is scarred to underlying episclera.

the latter as a Type II bleb. ${ }^{89}$ In failed blebs (Kronfeld's Type III), the scarred conjunctiva firmly adheres to the underlying episcleral tissue (Fig. 3).

Kronfeld's classification did not include the encapsulated bleb also known as a "Tenon's capsule cyst." 'I his localized, dome-shaped, cyst-like cavity of hypertrophied Tenon's capsule (Fig. 4) forms over the filtering site, usually by the third postoperative week, and entraps aqueous, resulting in increased intraocular pressure. ${ }^{185}$ Ocular massage, corticosteroids, and bleb needling or surgical revision may restore bleb function by reestablishing drainage of entrapped aqueous into the surrounding subconjunctival tissue. ${ }^{30,136,185}$

\section{B. HISTOPATHOLOGIC FINDINGS}

Addicks et al $^{1}$ have described a histopathologic

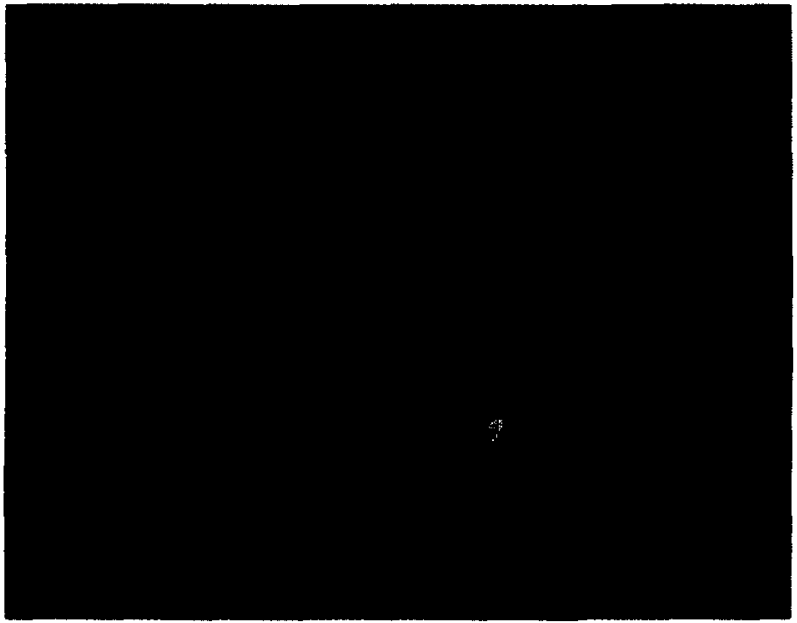

Fig. 2. Diffuse, slightly elevated bleb with relatively avascular appearance in comparison to surrounding conjunctiva.

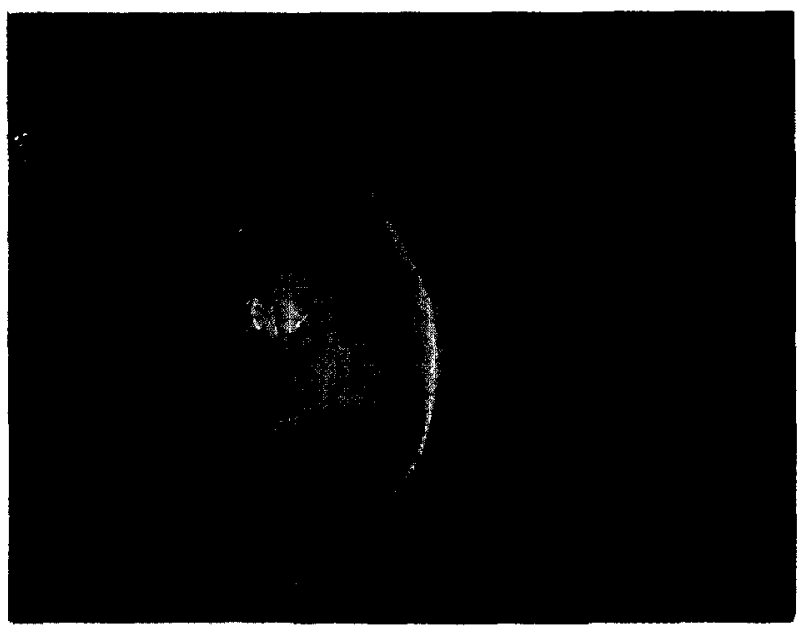

Fig. 4. Encapsulated bleb with characteristic vascular, dome-shaped, cyst-like appearance.

appearance of loosely arranged connective tissue beneath the conjunctival epithelium in functioning blebs. At the light microscopic level, subepithelial clear spaces corresponded to conjunctival microcysts, which are seen clinically and indicate a functional filtering bleb (Figs. 5 and 6). With electron microscopy the loose connective tissue was observed to contain scattered but otherwise normal collagen fibrils with 50 to 200 micron channel-like spaces throughout the stroma. Both light and electron microscopy showed normal conjunctival epithelium with no junctions between the cells that would limit fluid flow. Failed blebs demonstrated abnormally thickened, dense collagenous connective tissue beneath the conjunctival epithelium, which appeared normal (Fig. 7). Fibroblasts and blood vessels were also seen within the connective tissue of failed blebs. 


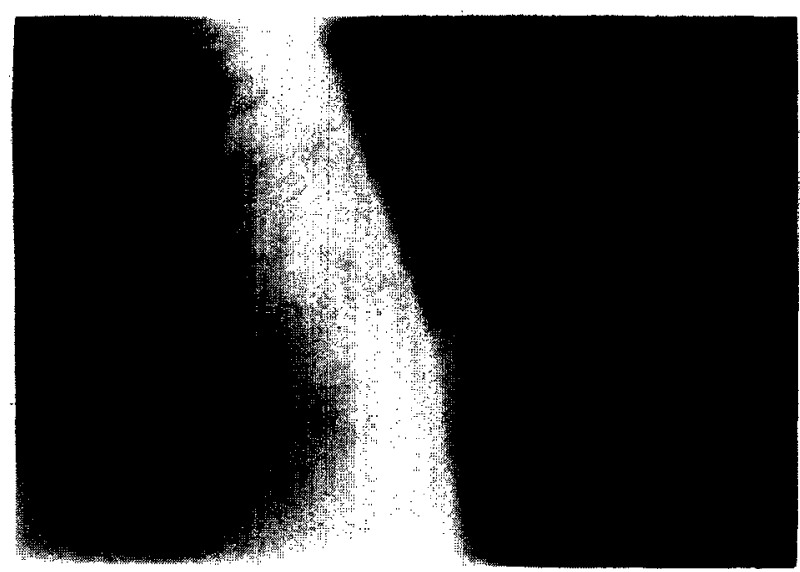

Fig. 5. Slit-lamp photograph showing microcystic spaces (arrows) to side of slit-lamp beam in functioning hleb. (Reprinted with permission from: Addicks EM, Quigley HA, Green WR, Robin AL: Histologic characteristics of filtering blebs in glaucomatous eyes. Arch Ophthalmol 101:795-798, 1983. Copyright 1983, American Medical Association.)

Histopathologically, the walls of encapsulated blebs were thin, almost avascular membranes which consisted of sheets of fibrous connective tissue with areas of active proliferation of fibroblasts. ${ }^{185}$ The cyst-like spaces of encapsulated blebs were lined by acellular material, which was probably fibrin, and not by surface epithelium, which lines true cysts.

\section{AQUEOUS PATHWAYS}

Addicks et al $^{1}$ proposed that subepithelial conjunctival microcysts represent channels for the passage of aqueous humor, which can follow two possible routes of egress. Aqueous can flow across the conjunctival epithelium into the tear film, ${ }^{88}$ or be directly absorbed by blood vessels in the subepithelial connective tissue. ${ }^{1,182}$

Similar pathways were also described by Teng et al, ${ }^{182}$ who further suggested that direct contact with aqueous degraded subconjunctival and episcleral collagen fibers and contributed to the production of thin multicystic blebs. ${ }^{182}$ Teng et al also theorized that aqueous may causc "loose pcrivascular degeneration" of episcleral and subconjunctival capillaries, which may facilitate filtration by increasing aqueous absorption directly through the blood vessel wall.

Another possible aqueous outflow pathway was identified in which the proliferating endothelium of cut capillaries contributed to the formation of anastomotic channels which could communicate directly with the deep scleral venous plexus. ${ }^{182}$ This mecha-

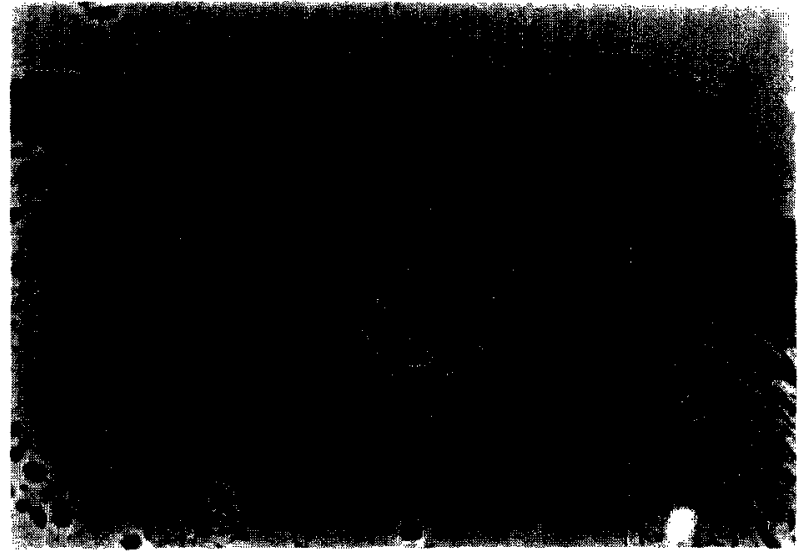

Fig. 6. Light micrographs correlating microcystic spaces (M) seen histologically with those seen clinically in Fig. 5 (paraphenylenediamine, $\times 310$ ). (Reprinted with permission from: Addicks EM, Quigley HA, Green WR, Robin AL: Histologic characteristics of filtering blebs in glaucomatous eyes. Arch Ophthalmol 101:795-798, 1983. Copyright 1983, American Medical Association.)

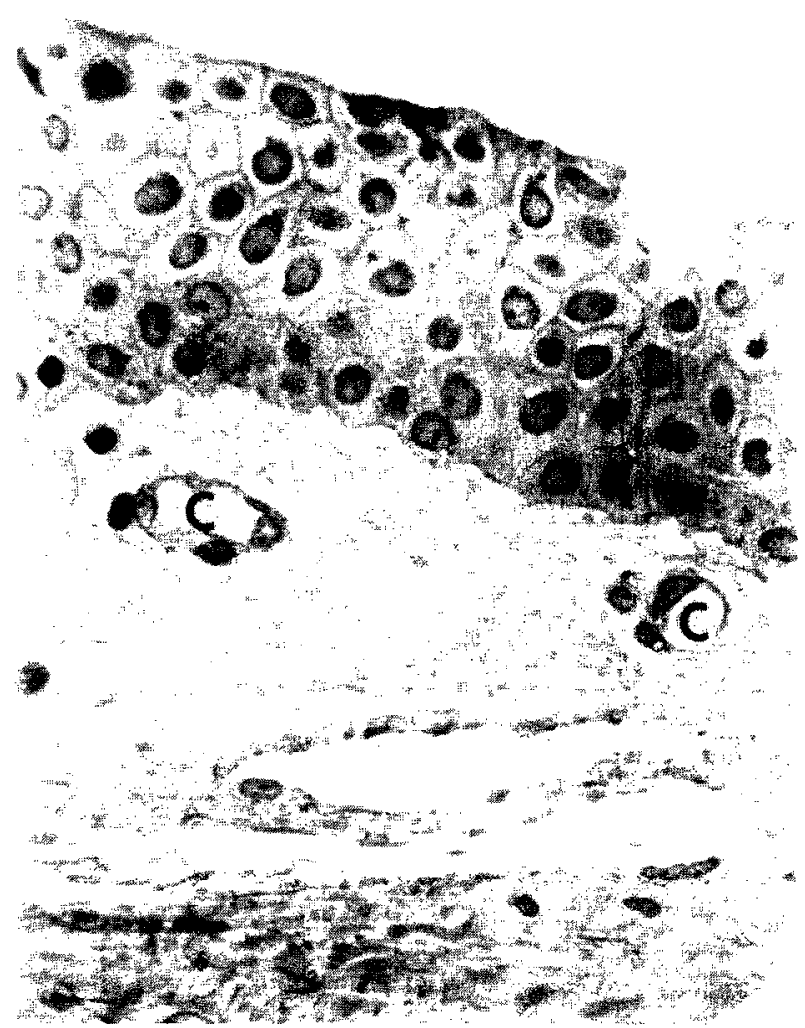

Fig. 7. Histologic appearance of failed bleb. Capillaries (C) present in subepithelial dense collagenous connective tissue (paraphenylenediamine, $\times 530$ ). (Reprinted with permission from: Addicks EM, Quigley HA, Green WR, Robin AL: Histologic characteristics of filtering blebs in glaucomatous eyes. Arch Ophthalmol 101:795-798, 1983. Copyright 1983, American Medical Association.) 
nism may explain postoperative intraocular pressure control without a visible bleb. Other explanations for intraocular pressure control in the absence of a bleb include an inadvertent cyclodialysis cleft $^{143,157}$ or aqueous outflow through the conjunctival lymphatic system. ${ }^{13,14}$

Direct aqueous flow through the cut ends of Schlemm's canal was originally theorized as the mechanism by which trabeculectomy reduced intraocular pressure; $;^{26}$ however, histologic findings do not support this route. ${ }^{143,173}$ The primary mechanism by which trabeculectomy lowers intraocular pressure is subconjunctival filtration. Whether aqueous passes through the partial thickness scleral flap, ${ }^{160}$ around the margins of the scleral flap, ${ }^{13}$ or both remains unclear. Possible aqueous pathways aftcr trabeculectomy are summarized in Fig. 8.

\section{Animal Models of Glaucoma Filtering Surgery}

Clinical and histopathologic observations in humans have contributed to our understanding of functional and nonfunctional blebs. Because the early events of GFS wound healing have not been well described in humans, animal models have been used to delineate the initial stages of wound healing.

\section{A. RABBITS}

Seetner and Morin described bleb formation after trabeculectomies in rabbits in the first few postoperative days. ${ }^{158}$ All blebs uniformly failed in 10-14 days. Histopathologically, fibrin clots were seen in the area of the trabeculectomy after two days. Fibroblastic proliferation, first noted after five days, proceeded to completely fill the trabeculectomy site with fibroblasts and newly formed collagen by the fourteenth postoperative day. The subconjunctival tissue was thickened on the fourteenth postoperative day, and cellular proliferation and new blood vessels were noted. By 30 days after surgery, the subconjunctival tissue was approaching normal thickness, little cellular proliferation was noted, and a dense collagenous scar was present. Miller et al performed thermosclerostomies in rabbits and similarly reported occlusion of the sclerostomies with fibrous tissue by the tenth postoperative day. ${ }^{117}$ These findings confirm previous observations in rabbits which had undergone trephinations. ${ }^{40,91}$

Rabbit eyes are poorly suited anatomically for use as GFS models. The ciliary processes are attached to the posterior surface of the iris to within $1 \mathrm{~mm}$ of the pupillary edge. ${ }^{137,138,152}$ Thus, iridectomy produces hemorrhage ${ }^{117}$ as well as destruction of the underlying ciliary processes. ${ }^{152}$ In addition, many of the zonular fibers of the large rabbit lens are inserted onto the anteriorly located ciliary processes. ${ }^{139}$

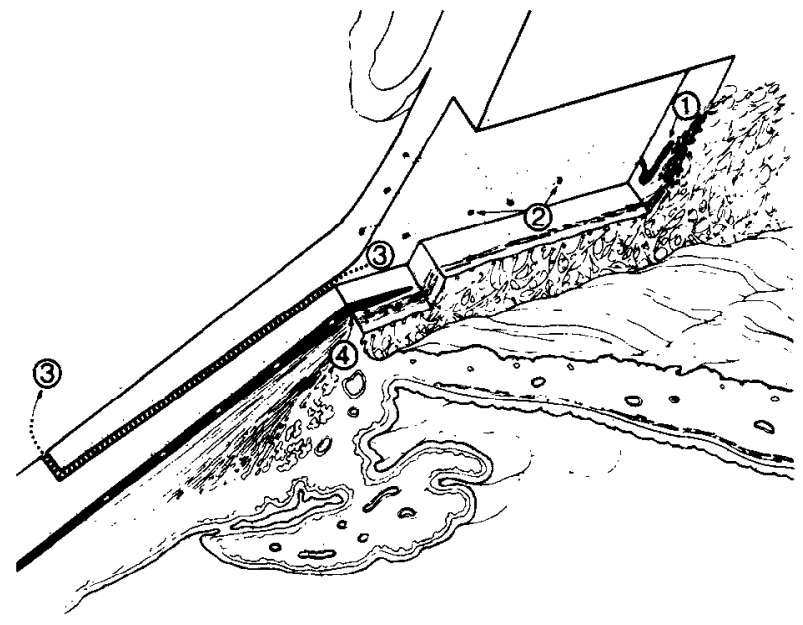

Fig. 8. Possible aqueous pathways after trabeculectomy include passage: (1) into cut ends of Schlemm's canal (not supported by histopathologic findings); (2) into intrascleral outflow channels or through thinned scleral lamellae; (3) around margins of scleral flap; and/or (4) into cyclodialysis cleft created during surgery. Aqueous that enters subconjunctival space may exit transconjunctivally or through absorption by blood vessels and/or conjunctival lymphatic system. (Reprinted with permission from: Spencer WH: Histologic evaluation of microsurgical glaucoma techniques. Trans Am Acad Ophthalmol Otolaryngol 76:389-397, 1972.)

\section{B. DOGS AND CATS}

Glaucoma filtering surgery in the eyes of dogs ${ }^{194}$ and cats ${ }^{148}$ has also been described. Because the iris is highly vascular and the major arterial arcade is present at the peripheral iris in both dogs ${ }^{106,175}$ and cats, ${ }^{107}$ severe anterior chamber hemorrhage may occur during iridectomy. ${ }^{106,175}$

\section{MONKEYS}

The anterior chamber anatomy of nonhuman primates is similar to that of humans ${ }^{11}$ and is well suited for study of GFS. Regan performed posterior lip sclerectomies and thermosclerostomies in monkeys and reported surgical success only with the latter procedure. ${ }^{142}$ Posterior lip sclerectomies were first filled by loose connective tissue followed by closely packed fibrous connective tissue secondary to fibroblast proliferation. In thermosclerostomies, obliteration of the drainage channel occurred if cautery was not applied to at least two-thirds the depth of the incision. The success was attributed to the cautery effects which produced scleral shrinkage, inhibition of neovascularization, and decreased fibroblastic proliferation necessary for wound healing. ${ }^{142,187}$ 
Desjardins et al also performed posterior lip sclerectomies in owl monkeys. ${ }^{34}$ They described three clinicohistopathologic phases of wound healing. In the first six days after surgery (early healing), the limbal fistulas generally remained open, although by day six, fibroblasts had begun to proliferate along the walls of the opening. Fibrinous material at the limbal fistula was seen in at least one eye early in the postoperative period. During the intermediate healing phase (days 7-9), continued proliferation and migration of fibroblasts, which were presumably derived from the adjacent episclera and subconjunctival tissue, were observed. Fibroblasts during the intermediate stage were predominantly oriented perpendicular to the corneoscleral lamellae. In the late healing phase (days 10-14), the limbal fistulas, with one exception, were completely closed by granulation tissue. The fibroblasts were oriented in a plane parallel to the cornea, a finding consistent with early wound remodeling and maturation.

In additional studies of the wound healing process after posterior lip sclerectomies in primates, Goodman et $\mathrm{al}^{54}$ noted initial plugging of the fistula with a fibrin/cellular clot (days 1-4). During days $7-14$, ingrowth of episcleral fibroblasts, migration of macrophages, blood vessel formation, and deposition of collagen were noted. As previously reported, ${ }^{34}$ complete closure of the fistula occurred by day $14 .^{54}$

A similar healing response was documented by Jampel et al, who utilized electron microscopy, immunohistochemical methods, and autoradiographic studies in addition to light microscopy. ${ }^{78}$ Autoradiographic techniques demonstrated cellular proliferation along the edges of the wound, in the conjunctival substantia propria, and in the cells lining episcleral blood vessels.

\section{Sequence of Events in Wound Healing}

Although recent studies have documented the early events of wound healing after GFS, our knowledge remains incomplete. In the context of general wound healing, ${ }^{39,132}$ observations in animal models $^{34,54,78,117,142,158}$ and after GFS in humans ${ }^{1,182}$ suggest a sequence of events in GFS wound healing that occurs in early bleb failure. After surgical trauma to the conjunctiva, episclera, and iris, blood vessels constrict, and leakage of plasma proteins (including fibrinogen, fibronectin, and plasminogen) and blood cells occurs. ${ }^{39,96}$ When exposed to tissue factors, ${ }^{5}$ plasma, or blood, or both clot to form a gel-like fibrin-fibronectin matrix, into which inflammatory cells (including monocytes and macrophages), new capillaries, and fibroblasts migrate.$^{34,39,54,78,158}$ Rabbit
Events of Wound Healing In GFS Failure

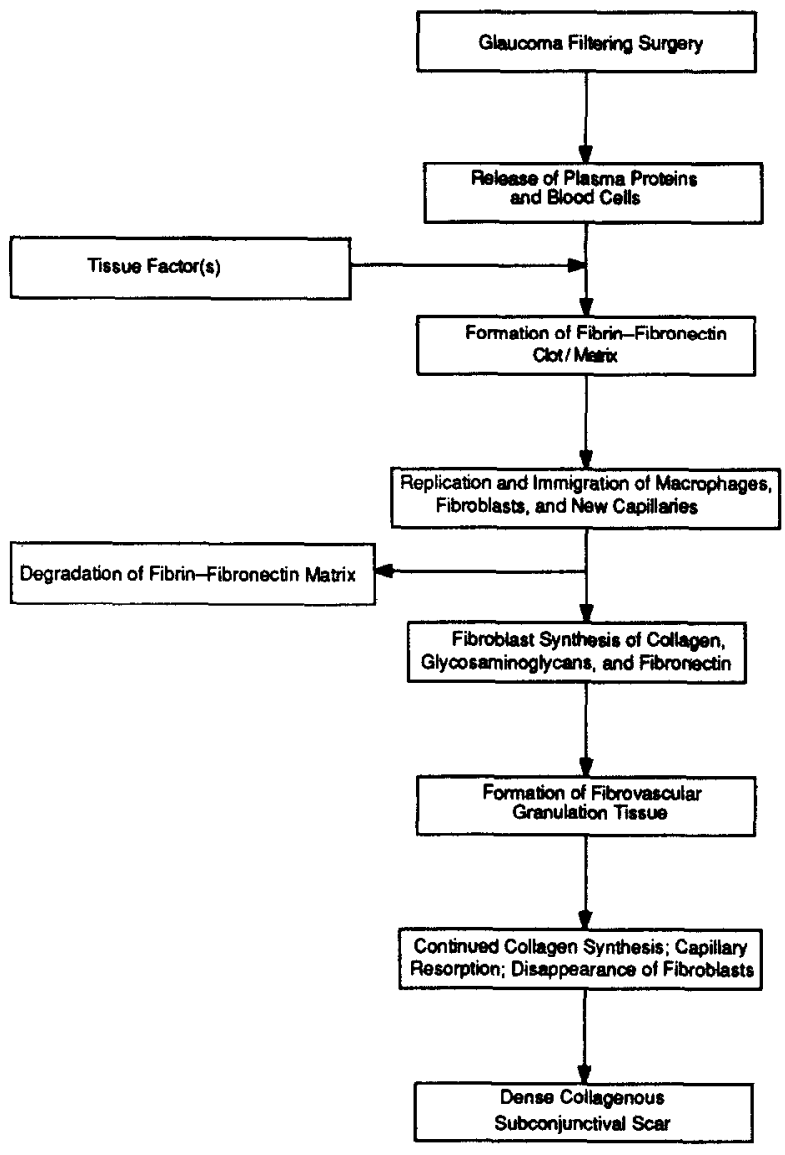

Fig. 9. Diagram of major stages of wound healing in early bleb failure after glaucoma filtering surgery.

and monkey studies indicate that fibroblast proliferation and migration after GFS begins around the fifth postoperative day ${ }^{34,158}$ and that the fibroblasts are derived from the edges of the wound, the subconjunctival tissue, and the episcleral tissue. ${ }^{34,78}$

The fibrin-fibronectin matrix is eventually degraded by inflammatory cells, ${ }^{39}$ and fibroblasts subsequently synthesize fibronectin, interstitial collagens, and glycosaminoglycans to form young fibrovascular connective tissue, also known as granulation tissue. ${ }^{34,39}$ Blood vessels are reabsorbed over time and fibroblasts largely disappear as the tissue is remodeled to form a dense collagenous subconjunctival scar with scattered fibroblasts and blood vessels. ${ }^{1,39}$ The events of wound healing in early GFS failure are summarized in Fig. 9.

Fibroblast proliferation and migration play prominent roles in GFS wound healing. ${ }^{34,54,78,158}$ Precisely which tissue factors are most important in the activation of fibroblasts after GFS is not known. What is known, however, is that a large number of factors appear to be chemotactic for fibroblasts in 
general. ${ }^{39}$ These include lymphokines, complement, native collagens of types I to $\mathrm{V}$, fibronectin, some proteolytic digestion fragments of collagen and fibronectin, and platelet-derived growth factor. The latter is a particularly potent mitogen and chemoattractant for fibroblasts. ${ }^{39,97,151,197}$ Future investigations may identify which of these factors play crucial roles in determining bleb failure.

\section{Anatomical and Physiological Factors Related to Bleb Failure}

\section{A. EXTERNAL FACTORS}

External factors at the episceral-conjunctival interface are responsible for most cases of GFS failure. ${ }^{1,112}$ In 1960 Maumenee proposed that the most likely cause of initial malfunction after filtering surgery was the failure of Tenon's capsule or subconjunctival tissue to absorb aqueous. ${ }^{108} \mathrm{He}$ later observed, however, that "in patients in whom filtration is destined to fail, even excision of most of the subconjunctival tissue will not prevent an impermeable layer of connective tissue from sealing off the wound in the first few postoperative days."109 Most observers now agree that fibroblast proliferation, synthesis of the extracellular matrix (collagen and glycosaminoglycans), and subsequent development of subconjunctival fibrosis play prominent roles in external failure. ${ }^{1,34,78,158}$ Addicks et al have also emphasized the possible role of synthesis of the extracellular matrix. ${ }^{1}$

\section{B. INTRAOCULAR AND SCLERAL FACTORS}

While the extraocular factors cited above are regarded as the primary cause of failure of GFS, intraocular and scleral factors have also been cited as potential causes of failure. ${ }^{108,109}$ Intraocular complications can lead to blockage of the filtration site by prolapse of lens, iris, vitreous, or ciliary body. An inadequate opening into the anterior chamber due to scleral remnants or Descemet's membrane in the fistula may also lead to primary failure. Many of these potential causes of bleb failure can be avoided by careful surgical technique. Performance of a basal iridectomy, anterior vitrectomy when indicated, and adequate removal of the sclerectomy specimen can enhance the likelihood of a patent fistula.

\section{INFLAMMATION AND BLOOD}

Intense preoperative and postoperative inflammation is undesirable ${ }^{46,109}$ because of the associated fibrinous and cellular responses and accelerated wound healing. Indeed, GFS success in patients with the uveitic glaucomas is generally poor. ${ }^{41,74}$

Clinical observations suggest that the presence of blood beneath the conjunctival flap postoperatively may also increase the probability of bleb failure ${ }^{46,164}$ though the specific effects of subconjunctival blood on wound healing have not been studied. As noted above, serum derivatives including fibronectin and platelet-derived growth factor may stimulate fibroblast migration and proliferation. ${ }^{97,197}$ In addition, macrophages, which may be activated by blood, appear to play a key role in inducing the fibroproliferative response in epiretinal membrane formation $^{116}$ and wound repair in general ${ }^{39,96,150}$ Extrapolation of these observations to GFS wound healing is consistent with the clinical impression that the presence of blood increases the likelihood of postoperative fibrosis.

\section{Clinical Factors Associated with Bleb Failure}

Kolker and Hetherington estimate an $80-90 \%$ success rate in glaucoma filtering surgery for primary open angle glaucoma (POAG) ${ }^{85}$ Success rates of $67 \%$ to $94 \%$ in the primary glaucomas (POAG and chronic angle closure glaucoma) have been reported. ${ }^{119,145,146,156,157,176,188}$ Youth, aphakia, active anterior segment neovascularization, previously failed GFS, and, possibly, race are risk factors associated with GFS failure.

\section{A. YOUTH}

Beauchamp and Parks reported $50 \%$ success in controlling intraocular pressure (11 of 22 eyes; IOP $\leq 24 \mathrm{~mm} \mathrm{Hg}$; mean follow-up 18 months) in children after trabeculectomy. ${ }^{9}$ A similar $52 \%$ success rate with trabeculectomy and thermosclerostomy in childhood glaucoma was described by Cadera et al (20 of 38 eyes; IOP $<22 \mathrm{~mm} \mathrm{Hg}$ with or without medications; mean follow-up 50 months), although five of the 20 successes had required a second filtering procedure. ${ }^{25}$ All patients in these two series were under age 20 years.

In a series of trabeculectomies in patients under age 50, Gressel et al reported success rates (IOP $\leq 21 \mathrm{~mm} \mathrm{Hg}$ with or without medications or 22-25 $\mathrm{mm} \mathrm{Hg}$ without medications) of $35 \%$ in the developmental glaucomas ( 6 of 17 eyes with mesodermal dysgenesis, Sturge-Weber syndrome, congenital rubella, primary infantile glaucoma, aniridia, or microcornea with congenital cataract) and $48 \%$ in the secondary glaucomas (24 of 50 eyes, most of which had trauma-associated glaucoma, inflammatory glaucoma, or previous ocular surgery) ${ }^{56}$ Trabeculectomies in patients age 30 to 49 with primary open angle glaucoma or chronic angle closure glaucoma resulted in $83 \%$ success ( 25 of 30 eyes), and were 
TABLE 1

Series of Trabeculectomy in Aphakic Eyes

\begin{tabular}{|c|c|c|c|c|c|}
\hline \multirow[b]{2}{*}{ Authors } & \multirow[b]{2}{*}{ Success Rate } & \multirow[b]{2}{*}{ Success Criteria } & \multirow{2}{*}{$\begin{array}{l}\text { Follow-up } \\
\text { (months) }\end{array}$} & \multicolumn{2}{|c|}{ Age (years) } \\
\hline & & & & Range & Mean \\
\hline Schwartz and Anderson ${ }^{156}$ & $4 / 12^{*} \dagger(33 \%)$ & IOP $\leq 20 \mathrm{~mm} \mathrm{Hg}$ & $\geq 4$ & $27-82$ & 60.4 \\
\hline Mehta et al ${ }^{113}$ & $16 / 23 * \quad(70 \%)$ & $\mathrm{IOP} \leq 21 \mathrm{~mm} \mathrm{Hg}$ & $0-16$ & - & - \\
\hline Herschler et al ${ }^{63}$ & $12 / 31 *(39 \%)$ & $\mathrm{IOP} \leq 20 \mathrm{~mm} \mathrm{Hg}$ & 12 & $5-95$ & 47 \\
\hline Singh and Singh ${ }^{166}$ & $35 / 40^{*} \quad(88 \%)$ & $\mathrm{IOP} \leq 20 \mathrm{~mm} \mathrm{Hg}$ & $>9$ & - & - \\
\hline Herschler ${ }^{66}$ & $21 / 28+\S(75 \%)$ & IOP $\leq 21 \mathrm{~mm} \mathrm{Hg}$ & $\geq 6$ & $19-80 \#$ & $61 \#$ \\
\hline Sharma and Singh ${ }^{159}$ & $23 / 25^{*}(92 \%)$ & $\mathrm{IOP}<22 \mathrm{~mm} \mathrm{Hg}$ & $? 2$ & $50-80$ & - \\
\hline Bellows and Johnstone ${ }^{12}$ & $12 / 20^{*} \dagger(60 \%)$ & $\mathrm{IOP} \leq 21 \mathrm{~mm} \mathrm{Hg}$ & $\geq 5$ & $15-83$ & 61.4 \\
\hline Heuer et al ${ }^{69}$ & $32 / 82^{*} \quad(39 \%)$ & $\begin{array}{l}\text { IOP } \leq 21 \mathrm{~mm} \mathrm{Hg} \text { with meds } \\
\text { IOP } \leq 25 \mathrm{~mm} \mathrm{Hg} \text { without meds }\end{array}$ & $\geq 6$ & $6-83$ & 59.1 \\
\hline
\end{tabular}

$\mathrm{IOP}=$ Intraocular pressure

*All cases were trabeculectomies.

†Fxcluding reoperations and cases of neovascular glaucoma.

$\S 70 \%$ of 47 cases in overall series were trabeculectomies.

\#Age range and mean for overall series of 41 patients.

- Not specified.

(Modified from Heuer DK, Gressel MG, Parrish RK II, et al: Trabeculectomy in aphakic eyes. Ophthalmology 91:1045-1051, 1984).

considerably more successful than in the small number of patients with the primary glaucomas below age 30 ( $44 \%$ success rate in four of nine eyes.)

Poor success rates in young patients have been attributed in part to previous ocular surgery, the thickness of Tenon's capsule, and a more vigorous healing response in youth. ${ }^{9}$ To our knowledge, the rate of ocular wound healing as determined by age has not been specifically evaluated. However, studies of wound healing in rats $\mathrm{s}^{73,178}$ and in vitro collagen biosynthesis by human skin ${ }^{184}$ support the concept of a more vigorous healing response in youth.

Holm-Pederson et al studied incisional skin wounds in young (2-3 months) and old (20-26 months) male rats and found delayed vascular proliferation and decreased early inflammation in older animals as compared to younger animals. ${ }^{73}$ Similarly, Sussman demonstrated that skin wounds in older rats synthesized less fibrous connective tissue than younger rats. ${ }^{178}$ Uitto reported a continual decrease in the amount of in vitro collagen synthesis by human skin from infancy up to age 30 to 35 , after which the rate remained essentially unchanged. ${ }^{184}$

The latter finding is of particular interest in relation to the observation of Gressel et al that patients over age 30 with the primary glaucomas demonstrated a success rate similar to those reported in older age groups. ${ }^{56}$ This suggests that, in the absence of additional confounding factors, the vigor of the healing response in young patients may be less important after a particular age.

\section{B. APHAKIA}

Reported success rates of GFS in aphakia vary from $33 \%$ to $92 \%$ though most large series report distinctly diminished success rates (Table 1). ${ }^{12,63,66,69,113,156,159,166}$ In the largest series by Heuer et al (82 eyes), a $39 \%$ overall success rate was reported, including a $5 \%$ success rate in patients under age 50.69

It is not completely understood why trabeculectomies so frequently fail in aphakic eyes. Heuer et al speculate that previous conjunctival scarring at the operative site may unfavorably influence the surgical outcome. However, Herschler has stated that selection of unscarred conjunctiva for GFS after lens extraction did not increase the surgical success. ${ }^{66,67}$ Vitreous incarceration into the filtering site has been described as a cause of bleb failure in aphakic eyes, ${ }^{108,109,156}$ although Herschler et al observed that such vitreous incarceration was not necessarily associated with failure of filtration. ${ }^{63} \mathrm{He}$ offered an alternative hypothesis that the primary cause of GFS failure in aphakic cyes was related to biological alteration of the aqueous by a fibroblast stimulant released from the vitreous and that removal of the vitreous would therefore increase surgical success. ${ }^{66}$ In support of this hypothesis, he reported $75 \%$ success (IOP $\leq 21 \mathrm{~mm} \mathrm{Hg}$; follow-up $\geq 6$ months) after one filtering procedure in 28 nonneovascular aphakic eyes that underwent total vitrectomy either prior to or combined with GFS. ${ }^{66}$ 
TABLE 2

Series of Glaucoma Filtering Surgery in Blacks

\begin{tabular}{|c|c|c|c|c|c|c|c|}
\hline \multirow[b]{2}{*}{ Authors } & \multirow[b]{2}{*}{ Procedure } & \multirow[b]{2}{*}{ Success } & \multirow[b]{2}{*}{ s Rate } & \multirow[b]{2}{*}{ Success Criteria } & \multirow{2}{*}{$\begin{array}{c}\text { Follow-up } \\
\text { (months) }\end{array}$} & \multicolumn{2}{|c|}{ Age (years) } \\
\hline & & & & & & Range & Mean \\
\hline \multirow[t]{3}{*}{ Bakker and Manku ${ }^{6}$} & $\mathrm{~T}$ & $31 / 39$ & $(80 \%)$ & IOP $<22 \mathrm{~mm} \mathrm{Hg}$ & $>3$ & $20-75$ & 55.4 \\
\hline & $\mathrm{S}$ & $29 / 39$ & $(74 \%)$ & IOP $<22 \mathrm{~mm} \mathrm{Hg}$ & & & \\
\hline & $\mathbf{T}$ & $40 / 47$ & $(85 \%)$ & $\mathrm{IOP}<22 \mathrm{~mm} \mathrm{Hg}$ & $>3$ & $25-73$ & 51.7 \\
\hline David et al ${ }^{33}$ & $\mathbf{T}$ & $36 / 49$ & $(73 \%)$ & $1 \mathrm{OP}<20 \mathrm{~mm} \mathrm{Hg}$ & $>6$ & $35-75$ & - \\
\hline Welsh $^{191}$ & $\mathrm{~T}$ & $19 / 29$ & $(65 \%)$ & $\mathrm{IOP}<20 \mathrm{~mm} \mathrm{Hg}$ & $>3$ & - & - \\
\hline Miller and Barber ${ }^{118}$ & $\mathrm{~T}$ & $70 / 122$ & $(57 \%)$ & $\mathrm{IOP}<21 \mathrm{~mm} \mathrm{Hg}$ & $\geq 12$ & $0-80$ & 52.3 \\
\hline Merritt ${ }^{115}$ & $\mathrm{~T}(23), \mathbf{S}(4), \mathbf{P}(9)$ & $8 / 36$ & $(22 \%)$ & IOP $<22 \mathrm{~mm} \mathrm{Hg}$ & $\geq 6$ & $27-76$ & 57.2 \\
\hline Ferguson and Macdonald ${ }^{43}$ & $T$ & $42 / 50$ & $(84 \%)$ & IOP $\leq 21 \mathrm{~mm} \mathrm{Hg}$ & $\geq 24$ & $40-78$ & 58.5 \\
\hline Freedman et $\mathrm{al}^{45}$ & $\mathrm{~T}$ & $53 / 64$ & $(82 \%)$ & $\mathrm{IOP}<20 \mathrm{~mm} \mathrm{Hg}$ & 19 & - & 56.8 \\
\hline Thommy and Bhar ${ }^{183}$ & $\mathrm{~T}$ & $106 / 111$ & $(95 \%)$ & $\mathrm{IOP} \leq 20 \mathrm{~mm} \mathrm{Hg}$ & $\geq 6$ & $36-62$ & - \\
\hline \multirow[t]{2}{*}{ Kietzman $^{83}$} & $\mathbf{T}$ & $164 / 221$ & $(74 \%)$ & $\mathrm{IOP}=20 \mathrm{~mm} \mathrm{Hg}$ & $\geqq 4$ & - & - \\
\hline & $\mathrm{P}$ & $165 / 196$ & $(84 \%)$ & & & & \\
\hline Sandford-Smith ${ }^{153}$ & $\begin{array}{l}\mathrm{T} \\
\mathrm{P}\end{array}$ & $33 / 51$ & $(65 \%)$ & IOP $\leq 20 \mathrm{~mm} \mathrm{Hg}$ & $\geq 3$ & - & - \\
\hline Ben Sira and Ticho ${ }^{16}$ & + & $25 / 27$ & $(93 \%)$ & $\mathrm{IOP}<18 \mathrm{~mm} \mathrm{Hg}$ & $\geq 6$ & - & 36 \\
\hline Ben Ezra and Chirambo ${ }^{15}$ & $\mathrm{~T}$ & $79 / 100$ & $(79 \%)$ & $\mathrm{IOP}<21 \mathrm{~mm} \mathrm{Hg}$ & $2-12$ & $>50$ & - \\
\hline Schimek and Williamson ${ }^{154}$ & $\mathrm{~T}$ & $19 / 23$ & $(83 \%)$ & IOP $<20 \mathrm{~mm} \mathrm{Hg}$ & $>6$ & $48-83^{*}$ & $66.4^{*}$ \\
\hline
\end{tabular}

$\mathrm{T}=$ Trabeculectomy.

$\mathrm{S}=$ Scheie procedure (Thermosclerostomy).

$\mathbf{P}=$ Posterior lip sclerectomy

$+=9$ Lagrange sclerotomies, 6 Scheie procedures, 12 Elliot trephinations.

$*$ = Age range and mean for overall series, not just blacks.

$-=$ Not specified.

More recent studies also suggest that vitreous may stimulate fibroblast proliferation. ${ }^{186,193}$ Wiedemann et al have shown that bovine vitreous stimulated the proliferation of dermal fibroblasts in tissue culture. ${ }^{193}$ They believe that the active substance responsible for fibroblast proliferation is a noncollagenous protein with a molecular weight of about $14000 \mathrm{MW}$. If a vitreous factor is responsible for fibroblast proliferation and surgical failure in aphakic glaucoma, improved success may be expected in patients with intact posterior capsules. However, the validity of this expectation has not yet been carefully determined.

\section{ANTERIOR SEGMENT NEOVASCULARIZATION}

The likelihood of GFS success in neovascular glaucoma is poor. Heuer, for example, reported only $11 \%$ success in initial filtering procedures for neovascular glaucoma in 36 eyes. ${ }^{70}$ This poor prognosis may be explained in part by intraoperative hemorrhage during conjunctival dissection and iridectomy, which may subsequently stimulate postoperative scarring. ${ }^{46,164}$ Eycs with neovascular glaucoma often demonstrate marked inflammation preoperatively as well as postoperatively. This too may pro- vide a framework for accelerated wound healing. Breakdown of the blood-aqueous barrier and the associated leakage of serum proteins may provide an additional stimulus for fibroblast proliferation. ${ }^{140}$ In addition, fibrovascular proliferation from the iris at the site of the internal sclerectomy may contribute to surgical failure.

To minimize intraocular hemorrhage, Herschler recommended a modified filtering operation for neovascular glaucoma in which focal cauterization was applied to the iris and ciliary processes ${ }^{64,131} \mathrm{By}$ Heuer's criteria, this method achieved a $33 \%$ success rate. Allen et al reported $67 \%$ success (IOP $\leq 20 \mathrm{~mm} \mathrm{Hg}$ or $\leq 26 \mathrm{~mm} \mathrm{Hg}$ and stable optic nerves) in 24 eyes with neovascular glaucoma and emphasized the importance of preoperative panretinal photocoagulation, preoperative treatment of inflammation, and attention to intraoperative hemostasis as factors contributing to their higher success rate. $^{3}$

\section{PREVIOUSLY FAILED GLAUCOMA FILTERING SURGERY}

Failed GFS may be associated with a decreased rate of success in subsequent procedures. Although 
the reasons for this association are not known, an inherently greater healing response in some patients, operating in the site of previous surgery, and increased inflammation with repeat surgeries could be contributing factors. ${ }^{156}$

Kolker and Hetherington estimated at least a $50 \%$ success rate of repeat filtering procedures, ${ }^{86}$ but Schwartz and Anderson reported success (IOP $\leq 20 \mathrm{~mm} \mathrm{Hg}$ with or without medications; follow-up $\leq 4$ months) in only four of ten eyes with previously failed GFS. ${ }^{156}$ Inaba calculated an overall five-year $64 \%$ failure probability ( $36 \%$ success) with a life table method in 76 eyes (success: IOP $<21 \mathrm{~mm} \mathrm{Hg}$ with or without medications) after repeat trabcculectomies in Japan. ${ }^{77}$ Thirty-two of the eyes were in patients with congenital glaucoma, for which the failure probability after two or more surgical interventions was $80 \%$ ( $20 \%$ success). In a separate analysis in which eyes with congenital glacuoma were excluded, a $49 \%$ failure probability $(51 \%$ success) after repeat trabeculectomies in 19 eyes with primary open angle glaucoma (POAG) and a $53 \%$ failure probability ( $47 \%$ success) in 17 eyes with primary angle closure glaucoma (PACG) were reported.

The failure probabilities were higher after repeat trabeculectomies than after single trabeculectomies in POAG (40\%, 132 eyes) and PACG (48\%, 130 eyes), ${ }^{77}$ although these differences were less than might be expected. Many more patients in the single and repeat trabeculectomy groups would be needed to statistically differentiate their success rates. Perhaps the general impression that repeated filtering procedures do not fare as well is due to a disproportionate percentage of eyes with poor progress, e.g., congenital glaucoma, among those eyes undergoing such procedures.

\section{E. RACE}

The clinical impression that GFS failure in blacks is more likely to occur is widely held. ${ }^{17,75,115}$ and has been attributed in part to an exuberant healing response exemplified by frequent hypertrophic scar (keloid) formation. ${ }^{46,190}$ However, several recent series have indicated surgical success rates of $73 \%$ to 95\% (Table 2). ${ }^{6,15,16,33,43,45,83,154,183}$ Although Miller and Barber reported overall success (IOP $\leq 21 \mathrm{~mm}$ $\mathrm{Hg}$ with medications or $<25 \mathrm{~mm} \mathrm{Hg}$ without medications; follow-up $>6$ months) in only $57 \%$ of blacks after trabeculectomy, the operation was successful in $82 \%$ of blacks over age $60 .{ }^{118}$ Whether race, independent of age, is a risk factor for bleb failure remains unsettled though the cited studies suggest that the surgical prognosis in blacks may be better than previously believed.

\section{Aqueous Humor Effects That May Enhance Bleb Formation}

\section{A. DIRECT EFFECTS}

Several investigators have emphasized the possible role of aqueous humor in bleb formation. Teng et al suggested that aqueous may have deleterious effects on mature collagen, but were unable to determine whether these effects were due to hydrolysis, solubilization, or enzyme action. ${ }^{182}$ They noted that if connective tissue at the surgical site was covered by endothelium, no degenerative effects were produced. In an animal model of GFS, Regan described scleral degeneration and "spongy" connective tissue in areas not covered by this singular layer of cells, which was presumably derived from the corneal endothelium..$^{142}$

To investigate the effects of aqueous on connective tissue, Chi et al placed autologous scleral implants into the anterior chambers of rabbit eyes. ${ }^{29}$ Most implants were encapsulated by endotheliallike cells and remained unchanged. The nonencapsulated implants underwent a decrease in cellularity, a loss of ground substance, and eventual disintegration of the collagen fibers.

Recent electron microscopic investigations documented that normal appearing collagen fibrils with a typical banding pattern were present in both functioning and failed blebs. ${ }^{1}$ A lack of specific collagen fibril abnormalities or other degenerative changes in filtering blebs have led Addicks et al to doubt the existence of a direct aqueous effect on collagen as an important factor in bleb formation.

\section{B. EFFECTS ON FIBROBLASTS}

Teng et al proposed that aqueous may inhibit collagen production by fibroblasts. ${ }^{182}$ Others had reported that surgical, ${ }^{32.62,110}$ traumatic, ${ }^{110}$ and ther$\mathrm{mal}^{169}$ iris wounds did not scar. While this observation may be partly due to mechanical separation of tissue, ${ }^{58}$ Snell speculated that aqueous may have an inhibitory effect on fibrosis. ${ }^{169}$ Inhibition of fibroblast proliferation by aqueous humor added to the nutrient medium in tissue culture has been reported with chick embryo fibroblasts, rabbit mesentery fibroblasts and rabbit iris. ${ }^{87}$

Herschler et al noted that primary aqueous obtained before surgery from 19 of 19 cataract patients and from 29 of 45 glaucoma patients inhibited the proliferation of the patients' own subconjunctival fibroblasts in tissue culture.$^{65} \mathrm{He}$ also described a significant positive correlation $(p<.01$, Wilcoxon two sample rank test) between successful filtering surgery and the inhibitory effect of $100 \%$ human aqueous on autologous fibroblasts in tissue culture. 
SKUTA AND PARRISH

Despite this positive correlation, interpretation may be confounded by (1) difficulty in disinguishing between a true inhibitory effect and a lack of sufficient nutrients; (2) the variability in the types of glaucoma patients included in the study (22 with POAG, nine with neovascular glaucoma, nine with aphakic glaucoma, one with uveitic glaucoma, and four with angle closure glaucoma); and (3) the inability to control for preoperative medications. Herschler noted that filtering blebs were maintained in some patients whose aqueous humor supported fibroblast proliferation and not in others whose aqueous did not support proliferation. ${ }^{65}$ Since preoperatively sampled aqueous (primary aqueous) had been used in this study, Herschler suggested that the effect of postoperative aqueous may be more important with respect to the ultimate success of GFS.

To test this hypothesis, Radius et al sampled aqueous before and after GFS in monkeys and found that initiation of monkey subconjunctival fibroblast proliferation in tissue culture was inhibited by primary aqueous humor but supported by postoperative aqueous. ${ }^{140}$ They offered two possible explanations for these findings: (1) primary aqueous humor lacks sufficient nutrient material, such as serum factors, to support fibroblast growth; and (2) factors present in postoperative aqueous inactivate the inhibitors of fibroblast proliferation that are normally present in the primary aqueous humor.

Addicks et al attributed these observations to the lack of appropriate nutrients in normal aqueous humor and release of plasma protein nutrients in postoperative aqueous resulting from breakdown of the blood-aqueous barrier. ${ }^{1}$ Since no specific aqueous antifibroblast substance has been isolated and aqueous under some conditions may stimulate fibroblast replication, ${ }^{2,140}$ further investigation to better determine the influence of aqueous biology and composition on GFS success is needed.

\section{Clinical Factors That May Enhance Bleb Formation}

\section{A. SURGICAL TECHNIQUE}

\section{Preoperative, Intraoperative, and Postoperative Care}

Speculation that changes in surgical techniques may increase success has led to a variety of modifications. It is not our purpose to review all recent surgical variations in GFS; however, we wish to emphasize the importance of the general principles of preoperative, operative, and postoperative care that may reduce postoperative scarring. Preoperative inflammation should be treated with antiinflammatory agents, usually corticosteroids, and
TABLE 3

Complications of Glaucoma Filtering Surgery

\begin{tabular}{lcc}
\hline & $\begin{array}{c}\text { Trabecul- } \\
\text { ectomy } \\
(\mathrm{n}=48)\end{array}$ & $\begin{array}{c}\text { Thermo- } \\
\text { sclerostomy } \\
(\mathrm{n}=50)\end{array}$ \\
\hline $\begin{array}{l}\text { Early Postoperative } \\
\quad \text { Flat anterior chamber }\end{array}$ & 2 & 10 \\
$\quad$ Shallow anterior chamber & 13 & 26 \\
Late Postoperative & & \\
$\quad$ Cataract requiring extraction & 0 & 10 \\
Thin bleb & & \\
$\quad$ 1 year & 8 & 22 \\
2 years & 10 & 21 \\
Perforated bleb & 0 & 2 \\
Infected bleb & 0 & 2 \\
Hypotony, 10 mm Hg & & 10 \\
1 year & 5 & 9 \\
2 years & 4 & 3 \\
Need for further glaucoma surgery & & 4 \\
$\quad$ Bleb revision & 3 & \\
$\quad$ Refilter & 1 & \\
\hline
\end{tabular}

Modified from Blondeau P, Phelps CD: Trabeculectomy vs thermosclerostomy; A randomized prospective clinical trial. Arch Ophthalmol 99:810-816, 1981 (Copyright 1981, American Medical Association).

miotics such as echothiophate iodide, which breaks down the blood-aqueous barrier, ${ }^{162}$ should be discontinued at least two weeks before GFS. Postoperative treatment of inflammation with topical and sometimes systemic corticosteroids and cycloplegic agents, usually atropine, is also important. Cycloplegic agents help restore the blood-aqueous barrier ${ }^{59}$ and may reduce the release of plasma proteins, which may contribute to the postoperative healing response. ${ }^{39}$ With respect to surgical technique, tissue trauma should be minimized and unnecessary manipulation of the conjunctiva and iris avoided. Meticulous hemostasis should be performed to decrease bleeding under the conjunctival flap. Removal of the inner sclerectomy block should establish a patent channel without remnants of Descemet's membrane. A basal iridectomy prevents postoperative iris incarceration at the filtering site. An anterior vitrectomy should be performed when postoperative vitreous could potentially obstruct the filtering site.

\section{Full-thickness Versus Partial-Thickness Procedures}

The surgical results and complications after fullthickness procedures and trabeculectomies represent an important clinical issue with implications on the wound healing response. In a prospective randomized clinical trial comparing trabeculectomy (48 eyes) to thermosclerostomy ( 50 eyes), Blondeau 
TABLE 4

Series Comparing Trabeculectomy to Full Thickness Procedures

\begin{tabular}{|c|c|c|c|c|c|c|c|}
\hline \multirow[b]{2}{*}{ Authors } & \multirow[b]{2}{*}{ Procedure } & \multirow[b]{2}{*}{ Success Rate } & \multirow{2}{*}{$\begin{array}{c}\text { Post-op IOP } \\
(\mathrm{mm} \mathrm{Hg})\end{array}$} & \multirow[b]{2}{*}{ Success Criteria } & \multirow{2}{*}{$\begin{array}{l}\text { Follow-up } \\
\text { (months) }\end{array}$} & \multicolumn{2}{|c|}{ Age (years) } \\
\hline & & & & & & Range & Mean \\
\hline \multirow[t]{4}{*}{ Blondeau and Phelps ${ }^{18}$} & $\mathrm{~T}$ & $34 / 42(81 \%)$ & 17.1 & $<22 \mathrm{~mm} \mathrm{Hg}$ & 12 & - & 59.3 \\
\hline & $\mathrm{S}$ & $40 / 44(91 \%)$ & 13.9 & $<22 \mathrm{~mm} \mathrm{Hg}$ & 12 & - & 60.1 \\
\hline & $\mathrm{T}$ & $32 / 37(86 \%)$ & 15.9 & $<22 \mathrm{~mm} \mathrm{Hg}$ & 24 & - & 59.3 \\
\hline & $\mathrm{S}$ & $32 / 35(91 \%)$ & 13.0 & $<22 \mathrm{~mm} \mathrm{Hg}$ & 24 & - & 60.1 \\
\hline \multirow[t]{2}{*}{ Lewis and Phelps ${ }^{98}$} & $\mathrm{~T}$ & $35 / 37(95 \%)$ & 16.2 & $<22 \mathrm{~mm} \mathrm{Hg}$ & 60 & - & 58.6 \\
\hline & $\mathrm{S}$ & $31 / 34(91 \%)$ & 15.7 & $<22 \mathrm{~mm} \mathrm{Hg}$ & 60 & - & 60.0 \\
\hline \multirow[t]{2}{*}{ Shields ${ }^{161}$} & $\mathrm{~T}$ & $21 / 26(81 \%)$ & 15 & $\leq 21 \mathrm{~mm} \mathrm{Hg}$ & 20 & $6-74$ & 38 \\
\hline & $\mathrm{P}$ & $20 / 23(87 \%)$ & 14 & $\leq 21 \mathrm{~mm} \mathrm{Hg}$ & 12 & $6-81$ & 46 \\
\hline \multirow[t]{2}{*}{ Drance and Vargas ${ }^{37}$} & $\mathrm{~T}$ & $33 / 36(92 \%)$ & - & $<20 \mathrm{~mm} \mathrm{Hg}$ & 36 & - & - \\
\hline & $\mathbf{S}$ & $18 / 22(82 \%)$ & - & $<20 \mathrm{~mm} \mathrm{Hg}$ & 36 & - & - \\
\hline \multirow[t]{3}{*}{ Schwartz PL et al ${ }^{157}$} & $\Gamma$ & $25 / 27(93 \%)$ & - & $<20 \mathrm{~mm} \mathrm{Hg}$ & 20 eyes $\geq 6$ & $31-82$ & 59.7 \\
\hline & P or Treph & $17 / 22(77 \%)$ & - & $<20 \mathrm{~mm} \mathrm{Hg}$ & 19 eyes $\geq 6$ & $48-72$ & 61.0 \\
\hline & & & $\mathrm{s} \mathrm{tx}^{*} \mathrm{ct} \mathrm{x}^{* *}$ & & & & \\
\hline \multirow[t]{2}{*}{ Spaeth $^{171,172}$} & $T$ & $10 / 13(77 \%)$ & $22.2 \quad 17.1$ & "Control of glaucoma" & $\geq 60$ & $15-80$ & - \\
\hline & $\mathrm{S}$ & $12 / 13(92 \%)$ & $16.5 \quad 13.5$ & "Control of glaucoma" & $\geq 60$ & $15-80$ & - \\
\hline \multirow[t]{2}{*}{ Spaeth $^{170}$} & $' \mathrm{l}$ & $16 / 22(73 \%)$ & 16.6 & "Control of glaucoma" & 36 & - & 59.7 \\
\hline & $\mathrm{S}$ & $23 / 27(85 \%)$ & 12.3 & "Control of glaucoma" & 36 & - & 53.4 \\
\hline \multirow[t]{2}{*}{ Watkins and Brubaker ${ }^{189}$} & $\mathrm{~T}$ & $--/ 49$ & 17 & - & $\geq 12$ & $15-80$ & $62+$ \\
\hline & Treph & $--/ 27$ & 15 & - & $\geq 12$ & $38-85$ & $65+$ \\
\hline
\end{tabular}

$T=$ Trabeculectomy

$\mathrm{S}=$ Scheie procedure (Thermosclerostomy).

$\mathrm{P}=$ Posterior lip sclerectomy.

Treph $=$ Trephination.

* = Without medications.

** = With medications.

$+=$ Median age.

$\ldots$ - Not specified.

and Phelps reported that thermosclerostomy lowered IOP approximately $3 \mathrm{~mm} \mathrm{Hg}$ more than trabeculectomy (average follow-up 2.7 years). ${ }^{18}$ However, the percentage of eyes with intraocular pressures less than $22 \mathrm{~mm} \mathrm{Hg}$ was not significantly different for the two operations. Postoperative complications such as flat anterior chamber, decrease in visual acuity, cataract, hypotony, and thin bleb with late infection or perforation occurred more frequently after thermosclerostomy (Table 3 ). Similar findings have been reported by others (Table 4). ${ }^{37,98,161,170,171,172,189}$ In short, successful trabeculectomy appears to decrease the incidence of postoperative complications but produces thicker more diffuse blebs and slightly higher postoperative intraocular pressures than full-thickness procedures.

\section{Excision of Tenon's Capsule}

The effect of the excision of Tenon's capsule on GFS success is questionable. Welsh suggested that Tenon's capsule reacts to surgical trauma and provides fibroblasts, which close sclerostomies with fibrous tissue. ${ }^{190}$ Kietzman $^{83}$ and Ben Sira and Ticho ${ }^{16}$ attributed their 74-93\% GFS success rates in blacks to removal of Tenon's capsule. In contrast, Gorin reported $82 \%$ success by creating conjunctival flaps in which he dissected conjunctiva from Tenon's capsule to avoid extensive manipulation of Tenon's capsule. ${ }^{55}$ Maumenee, who initially theorized that bleb failure resulted from the inability of Tenon's capsule or the subconjunctival tissue to absorb aqueous, ${ }^{108}$ later concluded that excision of subconjunctival tissue did not enhance the surgical success rate but did produce thinner blebs when successful. ${ }^{109}$ Comparing trabeculectomy with or without tenonectomy, Kapetansky failed to establish a significant difference in postoperative IOPs in the two groups of patients. ${ }^{80}$

\section{Fornix-Versus Limbus-based Flap}

Although a fornix-based conjunctival flap ${ }^{101,163}$ might prevent scarring of the posterior conjunctiva and Tenon's capsule, randomized studies of limbusversus fornix-based conjunctival flaps in primary trabeculectomies failed to document significant differences in surgical success between the two techniques. ${ }^{163,183 a}$ The final appearance of the filtration blebs was similar and independent of the type of conjunctival flap, although Traverso et al noted a tendency toward more anteriorly positioned blebs early in the postoperative period with fornix-based flaps. ${ }^{183 a}$ Shuster et al speculated that the technical 
and theoretical advantages of the fornix-blased flap may be more important in glaucomas associated with youth, aphakia, uveitis, and previously operated conjunctiva. ${ }^{163}$ The validity of this speculation has not been proven.

\section{Beta Radiation}

The potential value of beta radiation to inhibit fibroblast proliferation in eyes at increased risk for postoperative scarring has been reported. Iliff, who believed that blacks were at increased risk for postoperative failure, recommended postoperative irradiation to the surgical site. ${ }^{75} \mathrm{He}$ initially reported that beta radiation increased success in 8 of 11 blacks, ${ }^{75}$ but later concluded that beta radiation did not substantially alter postoperative fibrosis. ${ }^{76}$

Successful filtration in eight of ten blacks was described by Cohen et al, who applied beta radiation after completion of surgery and one week and two weeks postoperatively. ${ }^{31}$ Fricdenwalde also rcported increased surgical success with postoperative radiation in eyes with a history of previous intraocular surgery, recent uveitis, postoperative hemorrhage in the anterior chamber or under the bleb, and essential iris atrophy. ${ }^{46}$ Successful use of 2200-5000 rad doses of beta radiation in eyes with previously failed surgery or neovascular glaucoma has been described by Cameron. ${ }^{27}$

Although beta radiation as an adjunctive therapy is not widely employed, some recent studies reflect renewed interest in its effects. In tissue culture, $\mathrm{Ne}$ varez et al have shown that 285 rads from a strontium 90 applicator and 300 rads from a linear accelerator decreased owl monkey Tenon's fibroblast proliferation after three days to $45 \%$ and $43 \%$, respectively, compared to controls. ${ }^{129}$ A dose of 1000 rads with the linear accelerator achieved an additional antiproliferative effect $(36 \%$ of control) although 3000 rads did not reduce fibroblast proliferation any more than 1000 rads. When measured seven days after treatment with 300,1000 , and 3000 rads from the linear accelerator, fibroblast proliferation was reduced to $44 \%, 14 \%$, and $14 \%$ of control values.

In a similar study, Friedman et al reported that single doses of beta irradiation as low as 500 rads werc cytotoxic to cultured conjunctival fibroblasts. ${ }^{47,48}$ They also assessed the postirradiation inflammatory response of normal rabbit conjunctiva to $2500 \mathrm{rad}$ doses from a strontium 90 source and reported no significant difference in the appearance of irradiated eyes compared to placebo eyes. ${ }^{47}$ Friedman et al have also investigated beta irradiation in an animal model of GFS. ${ }^{48}$ In one experiment, a single $2500 \mathrm{rad}$ dose of focal beta irradiation applied 24 hours before performing posterior lip sclerecto- mies in six rabbit eyes produced no difference in bleb survival and histologic appearance, as compared to operated eyes that did not receive adjuvant irradiation. In a second experiment, each of five eyes of five rabbits was given three $2000 \mathrm{rad}$ doses of beta irradiation - one to four days preoperatively, immediately before surgery, and one to three days postoperatively. ${ }^{48}$ Fellow eyes that were operated without preoperative or postoperative irradiation routinely developed bleb scarring in two to three weeks. In contrast, treated eyes demonstrated clinically functional blebs. Histologic evaluation indicated that the treated eyes had substantially less granulation tissue at the sclerectomy sites than the nonirradiated surgical sites.

Tissue culture studies suggested that beta irradiation may inhibit fibroblast proliferation at rad doses not previously associated with conjunctival ${ }^{180}$ and scleral ${ }^{28,79,190,181}$ necrosis and lenticular opacities. ${ }^{72,181}$ However, these complications may occur with $2000 \mathrm{rad}$ doses of beta irradiation, ${ }^{180,181}$ which are less than the total doses used to achieve functional blebs in a preliminary animal study ${ }^{48}$ and one clinical study. ${ }^{27}$ The therapeutic efficacy and potential complications of beta irradiation in conjunction with GFS remain to be defined.

\section{Implants in Glaucoma Filtering Surgery}

To enhance the GFS success rates in eyes with neovascular glaucoma and other glaucomas with poor surgical prognoses, a variety of modified filtering procedures with implants for aqueous drainage have been introduced. The most widely used drainage implants include the Denver-Krupin valve, ${ }^{90,179}$ the anterior chamber tube shunt to an encircling band (ACTSEB), ${ }^{155}$ and the Molteno implant. ${ }^{22,120-124}$ As discussion of these implants is outside the scope of this wound healing review, interested readers are referred to the references cited. ${ }^{124 a, 155 a, 155 b}$

\section{B. PHARMACOLOGIC MODULATION OF WOUND HEALING}

\section{Corticosteroids}

Postoperative corticosteroids have been widely used since Sugar described their apparent effects on filtration blebs. ${ }^{177}$ Their efficacy presumably results from inhibition of the inflammatory response, ${ }^{38,114,196}$ direct effects on fibroblasts and connective tissue, ${ }^{52}$ and inhibition of fibroblast proliferation. ${ }^{19,38,114} \mathrm{Spe}$ cific antiinflammatory effects include suppression of fibrin deposition, capillary permeability, migration of leukocytes and macrophages, and phagocytic activity. ${ }^{59,60,130}$ The inhibition of fibroblast proliferation by corticosteroids may be dose-dependent, as 


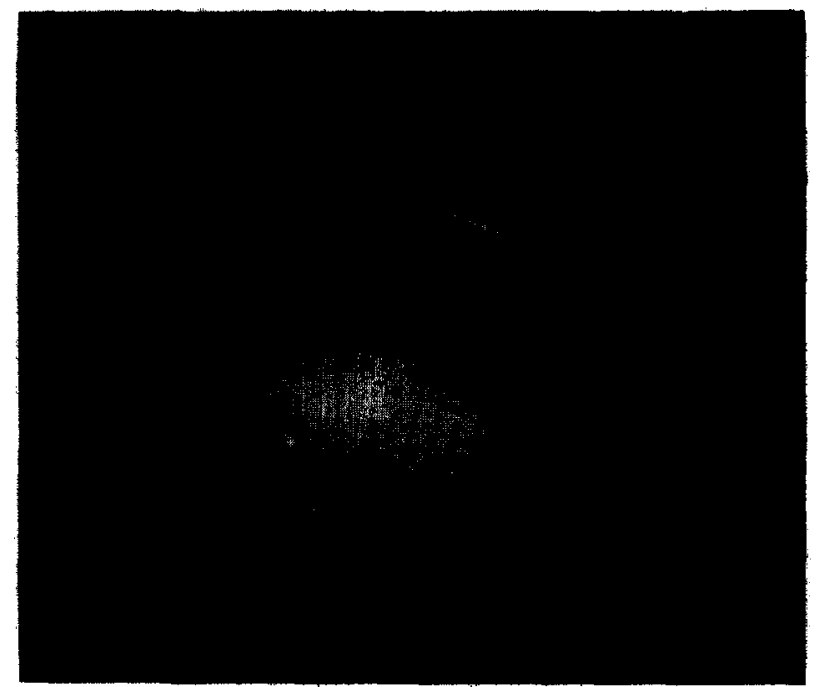

Fig. 10. Thin cystic filtering bleb 16 weeks after posterior lip sclerectomy in owl monkey treated with postoperative subconjunctival 5-FU. (Reprinted with permission from: Gressel MG, Parrish RK II, Folberg R: 5-fluorouracil and glaucoma filtering surgery: 1. An animal model. Ophthalmology 91:378-383, 1984.)

tissue culture studies have shown an increase in the replication rate of fibroblasts at low concentrations but an inhibitory effect at high concentrations. ${ }^{19}$ Corticosteroids produce a similar biphasic effect on protein and DNA synthesis by human subconjunctival fibroblasts in tissue culture. ${ }^{8}$

In a controlled trial to evaluate the clinical efficacy of postoperative corticosteroids in GFS, Starita et al reported a $96 \%$ success rate (stabilization of IOP, visual field, and optic nerve) in 25 eyes that received topical prednisolone acetate $1 \%$ compared to $76 \%$ success in 21 eyes that did not receive topical corticosteroids $\left(\mathrm{p}<.05\right.$, analysis of variance). ${ }^{174}$ Systemic prednisone given in addition to topical corticosteroids to 22 patients did not significantly improve success rates. Although eyes that received corticosteroids appeared to have thinner, more cystic blebs than eyes that did not receive corticosteroids, this observation was not statistically significant. The use of preoperative corticosteroids has also been advocated. Simmons has suggested initiation of both topical and systemic corticosteroids prior to surgery to blunt the inflammatory response. ${ }^{164}$

Many surgeons inject corticosteroids subconjunctivally after surgery, though these injections usually are not administered at the surgical site. Giangiacomo et al have proposed that preoperative subconjunctival corticosteroids injected directly at the filtering site may be beneficial. ${ }^{51}$ In each of 15 eyes at high risk for postoperative bleb failure, a $4 \mathrm{mg}$ subconjunctival injection of a long-acting depot corti-

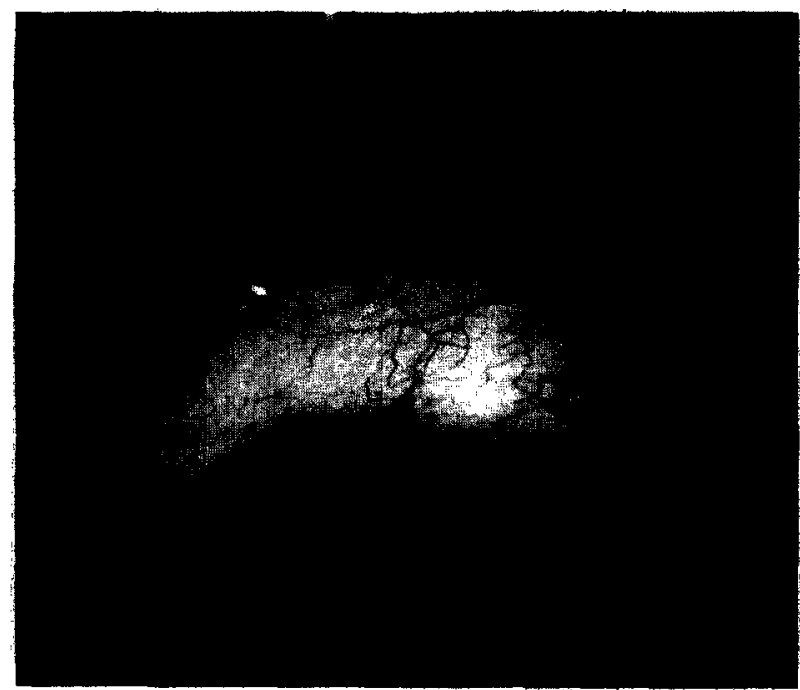

Fig. 11. Scarred conjunctiva at surgical site in control owl monkey eye 16 weeks after surgery. (Reprinted with permission from: Gressel MG, Parrish RK II, Folberg R: 5 fluorouracil and glaucoma filtering surgery: 1 . An animal model. Ophthalmology 91:378-383, 1984.)

costernid, triamcinolone acetonide, was administered at the surgical site one week preoperatively in 12 eyes, two days prior to surgery in one eye, and the day of surgery in two eyes. With a mean follow-up of 11.7 months, 14 of 15 eyes had intraocular pressures of $\leq 18 \mathrm{~mm} \mathrm{Hg}$ and diffuse microcystic blebs. No significant complications occurred in this pilot series, although cases of poor wound healing around the injection tracts and severe thinning or melting of the conjunctiva over the drug site have since been reported. ${ }^{53,194 a}$ The authors attributed the encouraging preliminary results to a localized cytocidal effect of the corticosteroid on adjacent fibroblasts, induction and lysis of macrophages, and alteration of collagen fibers in the vicinity of the injection in both humans and rabbits. ${ }^{52}$ They speculated that the release of potent degradative enzymes from lysed macrophages may account for some of the tissue effects.

In contrast, Ball described an increased fibroblast response in and around $8 \mathrm{mg}$ subconjunctival injections of triamcinolone acetonide in rabbits. ${ }^{7} \mathrm{He}$ also reported dense fibrous reactions around $12 \mathrm{mg}$ injections of the depot drug in three patients who subsequently underwent surgical bleb revisions. It is not known whether these contrasting observations are related to higher triamcinolone dosages, variations in surgical technique, or other factors. ${ }^{53}$ While the preliminary results of preoperative subconjunctival corticosteroids are encouraging, the need for a controlled clinic trial has been stressed by the authors..$^{51,52}$ 
SKUTA AND PARRISH

Fig. 12. Histology of 5-FU treated owl monkey eye, showing patent sclerectomy, basal iridectomy, and filtering bleb (hematoxylin-eosin, $\times 10)$. (Reprinted with permission from: Gressel MG, Parrish RK II, Folberg R: 5-fluorouracil and glaucoma filtering surgery: 1 . An animal model. Ophthalmology 91:378-383, 1984.)

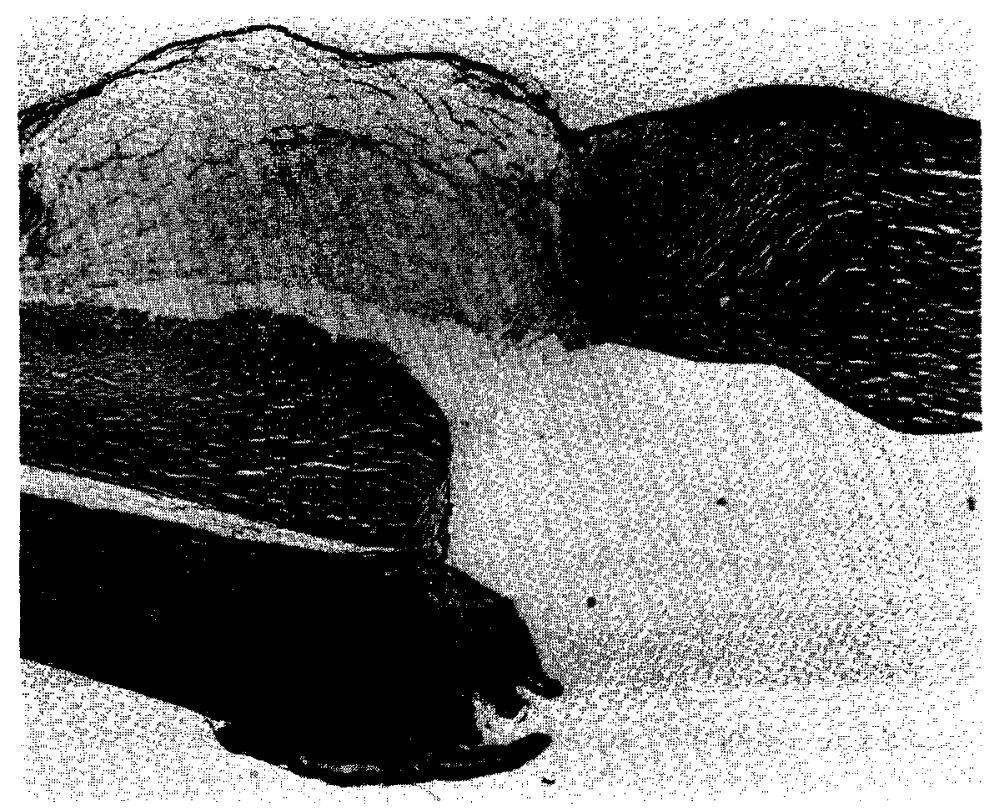

Fig. 13. Histology of control owl monkey eye. Basal iridectomy is present. Fibrovascular connective tissue bridges surgical site. No bleb is present (periodic acid-Schiff, $\times 10$ ). (Reprinted with permission from: Gressel MG, Parrish RK II, Folberg R: 5-fluorouracil and glaucoma filtering surgery: 1. An animal model. Ophthalmology 91:378-383, 1984.)

\section{Antimetabolites}

\section{a. 5-fluorouracil}

Recently, 5-fluorouracil (5-FU), a pyrimidine analog with antimetabolic activity, has gained attention as an adjuvant to GFS. This agent inhibits fibroblast proliferation in tissue culture ${ }^{19}$ and is believed to reduce postoperative scarring by decreasing fibroblast proliferation. ${ }^{57,68}$ Gressel et al described filtering blebs after four months in six of eight owl monkey eyes which received subconjunctival 5-FU and bleb failure in all control eyes within two weeks postoperatively (Figs. 10-13). ${ }^{57}$

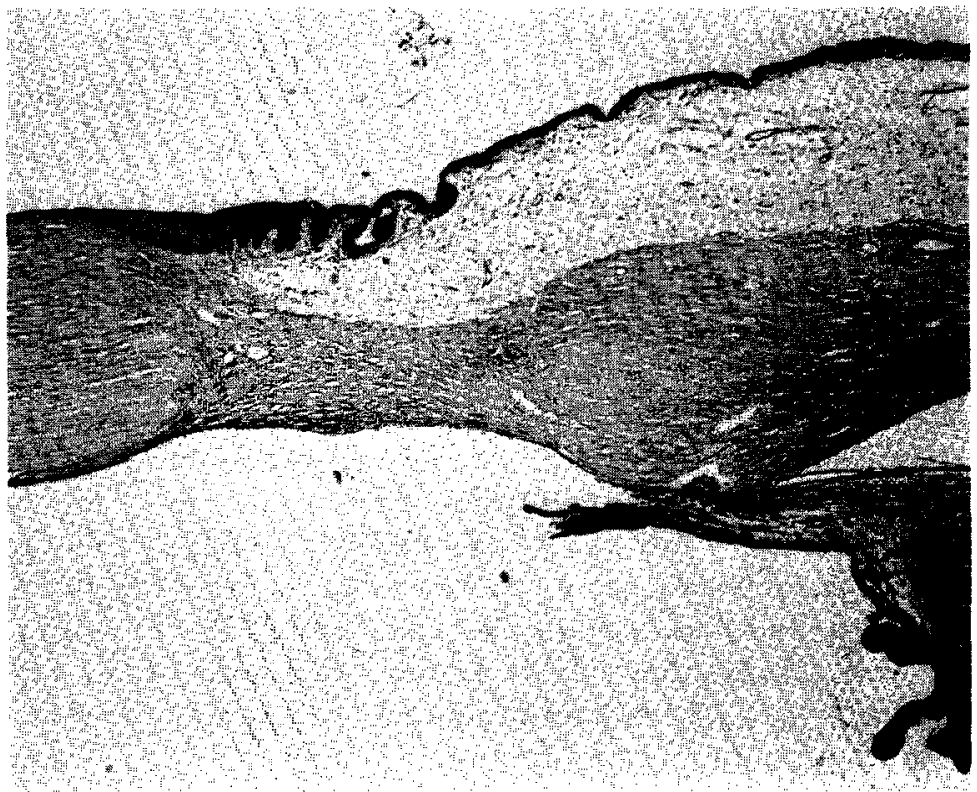

In a pilot study of postoperative subconjunctival 5-FU, Heuer et al reported increased success rates of GFS in high-risk patients with aphakia, neovascular glaucoma, or previously failed surgery. ${ }^{68,70}$ They defined success as intraocular pressure $\leq 21$ $\mathrm{mm} \mathrm{Hg}$ with or without ocular hypotensive medications or $22-25 \mathrm{~mm} \mathrm{Hg}$ without medications, with no further glaucoma surgical procedures. Successful results were reported in $68 \%$ of 48 aphakic eyes, $81 \%$ of 16 eyes with previously failed GFS, and $75 \%$ of 16 eyes with neovascular glaucoma. ${ }^{70}$ In a lifetable analysis of GFS in 88 aphakic eyes, 39 eyes with previously failed GFS, and 28 eyes with neo- 
vascular glaucoma, success rates at two years were $63 \%, 75 \%$, and $68 \%$, respectively. ${ }^{149}$ Additional studies of postoperative subconjunctival 5-FU have also reported enhanced success in eyes at high risk for surgical failure. ${ }^{151 a, 189 a}$

As a result of the antiproliferative effects of 5-FU, its administration is commonly associated with the development of conjunctival and corneal epithelial defects and conjunctival wound and suture tract leaks. ${ }^{68,70,149}$

In addition, severe corneal complications including bacterial corneal ulceration, sterile corneal ulceration, and development of a keratinized corneal plaque with an underlying sterile stromal infiltrate have recently been described in patients with preexisting corneal abnormalities who received postoperative 5-fluorouracil. ${ }^{84}$ Although success rates of GFS with subconjunctival 5-FU compare favorably with results in previous series of high risk patients, a clinical trial sponsored by the National Eye Institute is currently underway to evaluate the safety and efficacy of subconjunctivally injected 5-FU in aphakic or pseudophakic eyes and in those with prior unsuccessful GFS.

Since topical 5-FU would be more convenient than subconjunctival injections, the efficacy of this method of drug delivery has been evaluated in animal models. Pharmacokinetic studies in normal rabbit eyes showed that topically applied 5-FU achieved sufficient levels in the ocular compartments and tissues to have potential therapeutic applications. ${ }^{42}$ Topical administration of 5-FU after posterior lip sclerectomies in owl monkeys produced delayed bleb scarring. ${ }^{71}$ Seven of nine eyes developed corneal epithelial defects during topical therapy, and two corneas became opacified. The authors concluded that topical 5-FU may be more toxic to the cornea than subconjunctival administration.

\section{b. Other Antimetabolites}

While 5-fluorouracil has received the most attention in conjunction with GFS, other antimetabolic agents have also been studied. Trifluorothymidine,${ }^{147}$ doxorubicin hydrochloride, ${ }^{19}$ daunarubicin, ${ }^{111}$ bleomycin, ${ }^{92,99}$ and cytarabine (ara-C) $)^{92,99,102}$ inhibited proliferation of fibroblasts in tissue culture. Although cytarabine has not been used in conjunction with GFS, one potential advantage is the blockage of cytarabine-related ocular toxic effects by supplemental $2^{\prime}$-deoxycytidine. ${ }^{102}$ Bleomycin incorporated in a collagen polymer sponge was reported to enhance bleb survival in a rabbit model. ${ }^{82}$

Fluoropyrimidine analogs other than 5-fluorouracil have also demonstrated antiproliferative activity when tested in tissue culture. ${ }^{20,21}$ Fluorouridinc and its monophosphate ${ }^{21}$ were 50 to 100 times more potent than 5-fluorouracil on a weight/weight basis. Both $5^{\prime}$ fluorouridine $5^{\prime}$-monophosphate ${ }^{167}$ and 5fluoroorotate, ${ }^{54,61,61 a}$ another fluoropyrimidine, have been encapsulated in liposomes and tested in primate models of GFS (VIII. A. 1).

\section{Inhibitors of Collagen Cross-linking}

In the biosynthesis of collagen, procollagen is formed intracellularly by fibroblasts and is then secreted into the extracellular space, where the procollagen undergoes biochemical transformation into tropocollagen. ${ }^{192}$ The tropocollagen molecules then aggregate into immature soluble collagen fibrils, which, in turn, undergo cross-linking to form mature collagen with greater tensile strength.

Beta-aminopropionitrile (BAPN) and D-penicillamine, which inhibit collagen cross-linking and maintain a state of uncross-linked immature collagen, ${ }^{133}$ have received attention as potential adjuncts to reduce ocular scarring. Moorhead described (1) a significant effect of topical BAPN ointment in limiting contracture of the fornices after conjunctival alkali injuries in rabbits; ${ }^{125}$ (2) decreased posttraumatic vitreous proliferation in rabbits after both topical and systemic BAPN; ${ }^{126}$ and (3) the possible effectiveness of BAPN in enhancing longterm compliance and reducing refractive regression after radial keratotomy. ${ }^{127}$ The latter findings have been disputed by Busin et al. ${ }^{24}$

On the premise that BAPN may decrease the tensile strength of the scar at the filtering site and enhance the development of a functional bleb, topical BAPN ointment was administered for three months after GFS to each of 23 patients with aphakia, neovascular or uveitic glaucoma, or previously failed GFS. ${ }^{128}$ An overall success rate (IOP $\leq 21 \mathrm{~mm} \mathrm{Hg}$ with or without medications) of $74 \%$ was reported with a mean follow-up of $26.4 \pm 11$ weeks.

D-penicillamine, a copper chelator frequently used to treat Wilson's disease, is another lathyrogenic agent which acts at a different site than BAPN to prevent collagen cross-linking. ${ }^{133}$ (BAPN inhibits lysyl oxidase and prevents formation of aldol condensation side chains. D-penicillamine prevents cross-linking by chelating lysyl-derived aldehyde condensation bonds after they have formed. ${ }^{133}$ ) Dpenicillamine has been reported to decrease collagen synthesis by subconjunctival fibroblasts. ${ }^{111}$ In a rabbit model, subconjunctival injections of D-penicillamine prolonged the duration of bleb function after GFS; ${ }^{112 a}$ however, the use of D-penicillamine after GFS in humans has not been reported.

McGuigan et al have performed animal studies in which cynomolgus monkeys with laser-induced glaucoma underwent punch sclerectomies followed 
by adjunctive therapy with BAPN or penicillamine. ${ }^{12 b}$ Eyes treated with these agents maintained successful filtration for at least three days longer than control eyes, which received no drug treatment. The authors speculated that the lack of more prolonged effect on the patency of the sclerectomies could be explained by inadequate effective drug concentration or a biochemical action which affects only a minor portion of the healing process.

BAPN and D-penicillamine received attention as possible adjuvants due to their use in the treatment of keloids ${ }^{134}$ and urethral strictures. ${ }^{135}$ Although their inhibition of mature extracellular matrix production and the possible effects of post-GFS wound healing are of considerable interest, more definitive basic and clinical investigations will be necessary if the potential of these agents for use after GFS is to be determined. Currently, a multicenter randomized clinical trial is underway to investigate topical BAPN after reoperation in phakic eyes with previously failed glaucoma filtering surgery.

\section{Future Directions}

\section{A. MORE EFFECTIVE DRUG DELIVERY}

More effective drug delivery could be beneficial in improving surgical success rates after GFS. As noted, Giangiacomo et al recommended preoperative injection of corticosteroid depots at the operative site. ${ }^{51}$ Sustained delivery systems of antimetabolites have also been described to provide (1) a reduction in peak drug levels and a more sustained release of drug; (2) a more convenient administration of antimetabolite therapy, which currently often requires frcquent subconjunctival injections; ${ }^{68,70,149}$ and (3) a possible reduction in associated adverse effects. Sustained drug delivery from liposomes ${ }^{44,165,167}$ and slow release from bioerodable polymers ${ }^{94}$ and membranes $^{168}$ are being evaluated.

\section{Liposomes}

Liposomes are synthetic membrane-like vesicles consisting of phospholipid bilayers which alternate with aqueous compartments. ${ }^{95}$ Depending on the solubility properties, a drug can be encapsulated in the lipid bilayer or trapped in the aqueous compartment. The drug may then be slowly released as the vesicles are broken down to achieve sustained drug delivery.

Subconjunctivally injected liposomal 5-fluorouracil in rabbits has provided sustained delivery of 5fluorouracil. ${ }^{44,165}$ Pharmacokinctic studics of cytarabine entrapped in multivesicular liposomes have also been performed. Assil and Weinreb adminis- tered $6 \mathrm{mg}$ of subconjunctival cytarabine to $12 \mathrm{rab}$ bits and reported that the tissue half-life of drug at the injection site was 52.5 hours in the six rabbits treated with liposomal cytarabine compared to 0.2 hours in the six control animals treated with the same amount of drug in normal saline solution. ${ }^{4}$

Liposomal cytarabine and 5-fluorouracil have not yet been studied in animal models of GFS. Subconjunctival administration of other liposomally encapsulated fluoropyrimidines, including 5-fluorouridine $5^{\prime}$-monophosphate (5-FUMP) ${ }^{167}$ and 5fluoroorotate,$^{54}$ at the filtering site have enhanced duration of sclerectomy patency and bleb survival in primate models. Bone marrow aplasia in one animal and serious corneal complications in another animal were observed in the preliminary study of liposomal 5-FUMP, in which relatively high doses of the drug were used. ${ }^{167}$ It is possible that lower doses may still inhibit wound healing and avoid these adverse effects.

Winter et al have described histologically acute and chronic inflammatory changes in rabbits after subconjunctival injection of liposomes with and without 5-fluorouracil. ${ }^{195}$ An initial predominance of eosinophils at four hours after the injections was followed by a shift to neutrophils by 24 hours and to lymphocytes and plasma cells by 48 hours. At one week, macrophages infiltration, fibroblast proliferation, and angiogenesis were noted. The chronic infiltrate had decreased around the injection site after two weeks. It is not yet known whether this type of response occurs with liposomal preparations other than those used by Winter et al.

The relative importance of this potential inflammatory response associated with liposomes ${ }^{195}$ must be evaluated in the context of the sustained fibroblast inhibition that antimetabolites in a liposomal system may produce. In addition, the commercial feasibility of developing methods for the manufacture of stable and sterilizable liposomal preparations may be a determinant in their future availability. ${ }^{95,141}$

\section{Polymers and Membranes}

Lee et al studied a slow release biodegradable polymer [bis(p-carboxyphenoxy)hexane and sebacic acid] containing 5-fluorouracil which was used as a seton after posterior lip sclerectomies in rabbits. ${ }^{94}$ In eyes that received polymer setons with $10 \% 5$-FU, lower mean intraocular pressures were maintained in the period to "double failure" (return of IOP to within two $\mathrm{mm} \mathrm{Hg}$ of the preoperative starting pressure) as compared to eyes which did not reccive 5-FU. Howcver, the effect of 5-FU on prolonging time to failure was not statistically significant. 


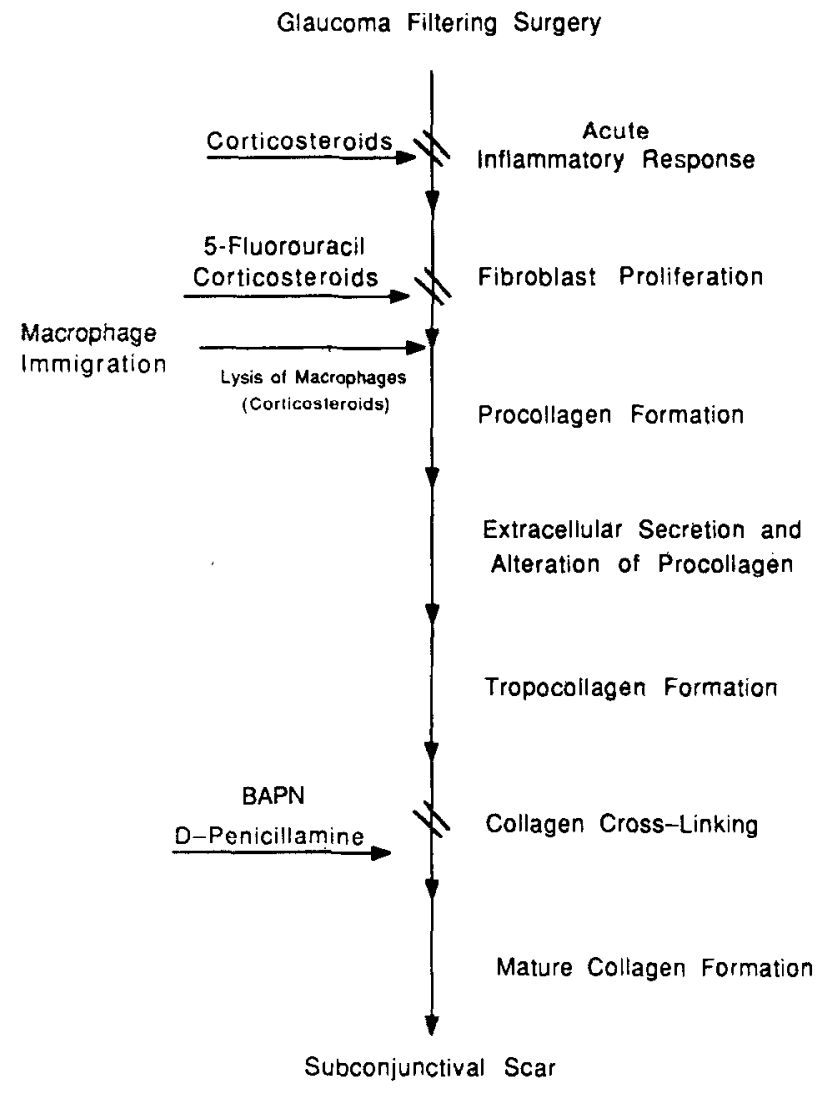

Fig. 14. Diagram of proposed inhibitory mechanisms of pharmacologic thcrapies at different stages of wound healing after glaucoma filtering surgery.

Polyvinyl alcohol membranes which permit linear release rates of $21.7 \mathrm{mg} / \mathrm{hr} / \mathrm{mm}^{2}$ of membrane have also been designed for sustained 5-FU administration. ${ }^{168}$ Pharmacokinetic and efficacy studies in animals have not been reported with this system.

Although investigation of sustained release systems for antimetabolites in GFS remains preliminary, the concept of controlled release to maximize the therapeutic effect and minimize relative toxicity is appealing.

\section{Combination Drug Therapy}

Combinations of pharmacologic modalities that affect different steps in the wound healing process, much like combination chemotherapy, could theoretically improve GFS success and minimize toxic effects. Corticosteroids, which decrease the inflammatory response $e^{38,59,60,114,196}$ and diminish release of plasma proteins and formation of the fibrin-fibronectin matrix early in the postoperative course, may reduce stimuli for fibroblast proliferation. As noted previously, high doses of corticosteroids may also have direct effects on fibroblasts and fibroblast proliferation..$^{8,19,52}$

Fibroblast proliferation, which becomes particu- larly important approximately five days postoperatively, ${ }^{34,158}$ can also be inhibited by antimetabolite therapy. ${ }^{19-21}$ Thus, topical corticosteroids, in combination with antimetabolite therapy, could be additive in inhibition of wound healing. Current regimens of subconjunctival 5-fluorouracil therapy also include intensive topical corticosteroid treatment. ${ }^{68,70,149}$

Blockage of collagen cross-linking by BAPN or Dpenicillamine or both is an additional step of wound healing which could be inhibited by combination therapy. These agents could maintain secreted collagen in a more soluble immature state during topical trcatment. ${ }^{128}$ Collagen which has failed to crosslink because of lathyrogenic therapy will remain uncross-linked. ${ }^{133}$ However, once this treatment is discontinued, collagen cross-linking of newly synthesized collagen would occur. At what point administration and discontinuation of lathyrogenic treatment would be appropriate is not known.

Attacking the wound healing process at multiple sites after GFS has considerable merit. How currently studied agents may affect wound healing is summarized in Fig. 14. It is likely that only through carefully controlled clinical trials will the efficacy and optimal timing of such therapy be established.

\section{B. SURGICAL INNOVATION}

Surgical modifications of conventional techniques and new applications of laser technology may provide areas for future development. Brown et al described an automated trephine which may be introduced across the anterior chamber to perform a full thickness sclerectomy ab interno. ${ }^{23}$ They propose that this method could provide access to filtering sites not easily accessible by conventional techniques, decrease surgical manipulation of conjunctival and episceral tissue, and reduce problems with wound and suture tract leaks associated with antimetabolite therapy.

Beckman et al first described the use of carbon dioxide lasers during GFS for creation of ab externo limbectomies in the early $1970 \mathrm{~s} .{ }^{10}$ More recently, ab interno full thickness sclerostomies and filtering blebs have been created with the neodymium-YAG laser using a gonioscopy lens in a living human eye, ${ }^{105}$ human cyc bank cyes, ${ }^{103}$ and the cyes of rabbits ${ }^{104}$ and nonhuman primates. ${ }^{50.104}$ With the use of fiberoptic systems introduced across the anterior chamber, ab interno sclerostomies have also been performed in enucleated human and bovine eyes with continuous wave ultraviolet and visible blue radiation from an argon laser, ${ }^{49,81}$ and in monkey eyes with a pulsed dye laser.$^{93}$ Scleral ablation with the excimer laser has been described ${ }^{16 a, 144}$ and may also be possible with the hydrogen fluoride laser. ${ }^{100}$ 
$\mathrm{Ab}$ interno laser sclerostomies could potentially reduce operative manipulation of the conjunctiva, and perhaps reduce the associated inflammatory and fibroproliferative responses.

\section{BETTER UNDERSTANDING OF WOUND HEALING}

Further understanding of wound healing after glaucoma filtering surgery will require a more precise delineation of the physiological and biochemical factors that affect early as well as late bleb failure. Identification of these factors may be possible by the application of information derived from other medical and surgical disciplines as well as by further ophthalmologic research. The considerable research effort in the cell biology of proliferative vitreoretinopathy may provide additional insight into wound healing after GFS. This information, in turn, may permit modulation of wound healing with minimization of potential adverse effects seen with current agents.

\section{Conclusions}

Wound healing after glaucoma filtering surgery depends on a wide variety of clinical, physiologic, surgical, and pharmacologic factors that may affect surgical success. We cannot predict which of the newer methods will prove to be most successful. However, a more complete knowledge of the principles of wound healing and new information derived from well controlled basic and clinical studies will enable us to better assess the safety and efficacy of current and future therapies.

\section{Acknowledgment}

The authors thank Elizabeth Hodapp, M.D. for reviewing the manuscript; Reva Hurtes and Donna Higgs for reviewing the bibliography; and Billie Ann Webb for secretarial services.

\section{References}

1. Addicks EM, Quigley HA, Green WR, Robin AL: Histologic characteristics of filtering blebs in glaucomatous eyes. Arch Ophthalmol 101:795-798, 1983

2. Albrink WS, Wallace AC: Aqueous humor as a tissue culture nutrient. Proc Soc Exp Biol Med 77:754-758, 1951

3. Allen RC, Bellows AR, Hutchinson BT, Murphy SD: Filtration surgery in the treatment of neovascular glaucoma. Ophthalmology 89:1181-1187, 1982

4. Assil KK, Weinreb RN: Multivesicular liposomes; sustained release of the antimetabolite cytarabine in the eye. Arch Ophthalmol 105:400-403, 1987

5. Bach R, Nemerson Y, Konigsberg W: Purification and characterization of bovine tissue factor. $J$ Biol Chem 256:8324-8331, 1981

6. Bakker NJA, Manku SI: Trabeculectomy versus Scheie's operation: a comparative retrospective study in open-angle glaucoma in Kenyans. Br J Ophthalmol 63:643-645, 1979

7. Ball SF: Effects of triamcinolone injection (letter). Arch Ophthalmol 104:1749-1750, 1986
8. Ball SF, Vinh T, Gebhardt BM: Biphasic effect of corticosteroids on protein and DNA synthesis by human subconjunctival fibroblasts in culture. ARVO Abstracts. Invest Ophthalmol Vis Sci (Suppl) 28:378, 1987

9. Beauchamp GR, Parks MM: Filtering surgery in children: barriers to success. Ophthalmology 86:170-180, 1979

10. Beckman H, Rota A, Barraco R, et al: Limbectomies, keratectomies, and keratostomies performed with a rapid-pulsed carbon dioxide laser. Am J Ophthalmol 71:1277-1283, 1971

11. Bellhorn RW: Laboratory animal ophthalmology, in Gelatt KN (ed): Textbook of Veterinary Ophthalmology. Philadelphia, Lea and Febiger, 1981, p 649

12. Bellows AR, Johnstone MA: Surgical management of chronic glaucoma in aphakia. Ophthalmology 90:807-813, 1983

13. Benedikt O: Zur Wirkungsweise der Trabekulektomie. Klin Monatsbl Augenheilkd 167:679-685, 1975

14. Benedikt O: Die Darstellung des Kammerwasserabflusses normaler und glaukomkranker menschilcher Augendurch Fullung der Vorderkammer mit Fluorescein. Graefes Arch Clin Exp Ophthalmol 199:45-67, 1976

15. BenEzra D, Chirambo MC: Trabeculectomy. Ann Ophthalmol 10:1101-1105, 1978

16. Ben Sira I, Ticho U: Excision of Tenon's capsule in fistulizing operations on Africans. Am J Ophthalmol 68:336-340, 1969

16a. Berlin MS, Rajacich G, Duffy M et al: Excimer laser photoablation in glaucoma filtering surgery. Am J Ophthalmol 103:713714,1987

17. Berson D, Zauberman H, Landau L, Blumenthal M: Filtering operations in Africans. Am J Ophthalmol 67:395-398, 1969

18. Blondeau P, Phelps CD: Trabeculectomy vs thermosclerostomy; A randomized prospective clinical trial. Arch Ophthalmol $99: 810-816,1981$

19. Blumenkranz MS, Glaflin A, Hajek AS: Selection of therapeutic agents for intraocular proliferative disease; cell culture evaluation. Arch Ophthalmol 102:598-604, 1984

20. Blumenkranz MS, Hartzer MK, Hajek AS: Selection of therapeutic agents for intraocular proliferative disease. II. Differing antiproliferative activity of the fluoropyrimidines. Arch Ophthalmol 105:396-399, 1987

21. Blumenkranz MS, Hajek A, Hernandez E, Hartzer M: Fluorouridine: a second generation ocular antimetabolite. ARVO Abstracts. Invest Ophthalmol Vis Sci (Suppl) 26:285, 1985

22. Brown RD, Cairns JE: Experience with the Molteno long tube implant. Trans Ophthalmol Soc UK 103:297-312, 1983

23. Brown RH, Denham DB, Bruner WE, et al: Internal sclerectomy for glaucoma filtering surgery with an automated trephine. Arch Ophthalmol 105:133-136, 1986

24. Busin M, Yau C-W, Yamaguchi T, et al: The effect of collagen cross-linkage inhibitors on rabbit corneas after radial keratotomy. Invest Ophthalmol Vis Sci 27:1001-1005, 1986

25. Cadera W, Pachtman MA, Cantor LB, et al: Filtering surgery in childhood glaucoma. Ophthalmic Surg 15:319-322, 1984

26. Cairns JE: Trabeculectomy; preliminary report of a new method. Am J Ophthalmol 66:673-679, 1968

27. Cameron ME: Beta irradiation as an adjunct to surgery in refractory glaucoma. Trans Aust Coll Ophthalmol 2:53-60, 1970

28. Cameron ME: Preventable complications of pterygium excision with beta-irradiation. $\mathrm{Br} J$ Ophthalmol 56:52-56, 1972

29. Chi HH, Teng CC, Katzin HM: Experimental implants of sclera into the anterior chamber. Am J Ophthalmol 46:534-541, 1958

30. Cohen JS, Shaffer RN, Hetherington J Jr, Hoskins D: Revision of filtration surgery. Arch Ophthalmol 95:1612-1615, 1977

31. Gohen LB, Graham TF, Fry WE: Beta radiation; as an adjunct to glaucoma surgery in the Negro. Am J Ophthalmol 47:54-61, 1959

32. Daniel RK: Healing of the iris in rabbits following experimental iridectomy. Arch Ophthalmol 31:292-298, 1944

33. David R, Freedman J, Luntz MH: Comparative study of Watson's and Cairns's trabeculectomies in a black population with open angle glaucoma. $\mathrm{Br} J$ Ophthalmol 61:117-119, 1977

34. Desjardins DC, Parrish RK II, Folberg R, et al: Wound healing after filtering surgery in owl monkeys. Arch Ophthalmol 104: $1835-1839,1986$ 
35. deWecker L: La cicatrice a filtration. Ann Oculist 87:133-143, 1882

36. Diegelmann RF, Cohen IK, Kaplan AM: The role of macrophages in wound repair: A review. Plast Reconstr Surg 68: $107-113,1981$

37. Drance SM, Vargas E: Trabeculectomy and thermosclerectomy: a comparison of two procedures. Can J Ophthalmol 8:413-415, 1973

38. Duke-Elder S, Ashton N: Action of cortisone on tissue reactions of inflammation and repair with special reference to the eye. $\mathrm{Br}$ J Ophthalmol 35:695-707, 1951

39. Dvorak HF: Tumors: Wounds that do not heal; similarities between tumor stroma generation and wound healing. $N$ EnglJ Med 315:1650-1659, 1986

40. Ellett EC: A study of the healing of trephine wounds of the sclera and corneoscleral junction. Trans Sect Ophthalmol, AMA, 390-394, 1914

41. Epstein DL: Glaucoma due to intraocular inflammation, in Epstein DL (ed): Chandler and Grant's Glaucoma. Philadelphia, Lea and Febiger, 1986, p 362

42. Fantes FE, Heuer DK, Parrish RK II, et al: Topical fluorouracil; pharmacokinetics in normal rabbit eyes. Arch Ophthalmol 103:953-955, 1985

43. Ferguson JG Jr, Macdonald R Jr: Trabeculectomy in blacks: a two-year follow-up. Ophthalmic Surg 8(6):41-43, 1977

44. Fishman P, Peyman G, Hendricks R: Intravitreal and subconjunctival liposome-encapsulated 5-FU in a rabbit model. ARVO Abstracts. Invest Ophthalmol Vis Sci (Suppl) 27:348, 1986

45. Freedman J, Shen E, Ahrens M: Trabeculectomy in a Black American glaucoma population. Br J Ophthalmol 60:573-574, 1976

46. Friedenwald JS: Some problems in the diagnosis and treatment of glaucoma. Am J Ophthalmol 33:1523-1538, 1950

47. Friedman SM, Dueker DK, Solomon HM, Wang RJ: The effect of beta radiation on normal rabbit conjunctiva and fibroblasts in culture. Invest Ophthalmol Vis Sci (Suppl) 27:212, 1986

48. Friedman SM, Dueker DK, Solomon HM: The effect of beta radiation on maintaining filtering blebs after glaucoma surgery in normal rabbits. ARVO Abstracts. Invest Ophthalmol Vis SCi (Suppl) 28:272, 1987

49. Gaasterland DE, Hennings DR, Boutacoff TA, Bilek C: Ab interno and ab externo filtering operations by laser contact surgery. Ophthalmic Surg 18:254-257, 1987

50. Gherezghiher T, March WF, Koss MC, Nordquist RE: Neodymium-YAG laser sclerostomy in primates. Arch Ophthalmol 103:1543-1545, 1985

51. Giangiacomo J, Dueker DK, Adelstein E: The effect of preoperative subconjunctival triamcinolonc administration on glaucoma filtration. I. Trabeculectomy following subconjunctival triamcinolone. Arch Ophthalmol 104:838-841, 1986

52. Giangiacomo J, Dueker DK, Adelstein EH: Histopathology of triamcinolone in the subconjunctiva. Ophthalmology 94: $149-153,1987$

53. Giangiacomo J, Dueker DK: Effects of triamcinolone injection (reply to letter). Arch Ophthalmol 104:1750, 1986

54. Goodman DF, Alvarado JA, Stern W, et al: Liposomal incorporated 5-fluoroorotate inhibition of wound healing following posterior lip sclerectomy in the primate. Invest Ophthalmol Vis Sci (Suppl) 28:271, 1987

55. Gorin G: Use of a thin conjunctival flap in limbosclerectomy. Ann Ophthalmol 3:258-263, 1971

56. Gressel MG, Heuer DK, Parrish RK II: Trabeculectomy in young patients. Ophthalmology 91:1242-1246, 1984

57. Gressel MG, Parrish RK II, Folberg R: 5-fluorouracil and glaucoma filtering surgery: I. An animal model. Ophthalmology 91:378-383, 1984

58. Hanna C, Roy FH: Iris wound healing. Arch Ophthalmol 88:296-304, 1972

59. Havener WH: Corticosteroid therapy, in Havener WH (ed): Ocular Pharmacology. St Louis, C V Mosby 1983, pp 437-442

60. Haynes RC Jr, Murad F: Adrenocorticotropic hormone; adrenocortical steroids and their synthetic analogs; inhibitors of adrenocortical steroid biosynthesis, in Gilman AG, Good- man LS, Rall TW, Murad F (eds): The Pharmacological Basis of Therapeutics. New York, MacMillan Publishing Co, 1985, pp 1471-1472

61. Heath TD, Lopez NG, Lewis GP, Stern WH: Liposomes as drug carriers in the treatment of PVR. ARVO Abstracts. Invest Ophthalmol Vis Sci (Suppl) 26:284, 1985

61a. Heath TD, Lopez NG, Lewis GP, Stern WH: Antiproliferative and anticontractile effects of liposome encapsulated fluoroorotate. Invest Ophthalmol Vis Sci 28:1365-1372,1987

62. Henderson T: The histology of iridectomy. Ophthalmic Review 26:191-202, 1907

63. Herschler J, Litinsky SM, Shaffer RN, et al: Surgical treatment of glaucoma in the aphakic patient, in Emery JM (ed): Current Concepts in Cataract Surgery; Selected Proceedings of the Fifth Biennial Cataract Surgical Congress. St Louis, CV Mosby, 1978, pp $426-428$

64. Herschler J, Agness D: A modified filtering operation for neovascular glaucoma. Arch Ophthalmol 97:2339-2341, 1979

65. Herschler J, Claflin AJ, Fiorentino G: The effect of aqueous humor on the growth of subconjunctival fibroblasts in tissue culture and its implications for glaucoma surgery. Am J $O_{p h-}$ thalmol 89:245-249, 1980

66 . Herschler $\mathrm{J}$ : The effect of total vitrectomy on filtration surgery in the aphakic cyc. Ophthalmology 88:229-232, 1981

67. Herschler J: Medically uncontrolled glaucoma in the aphakic eye. Ann Ophthalmol 13:909, 1981

68. Heuer DK, Parrish RK II, Gressel MG, et al: 5-fluorouracil and glaucoma filtering surgery. II. A pilot study. Ophthalmology 91:384-393, 1984

69. Heuer DK, Gressel MG, Parrish RK II, et al: Trabeculectomy in aphakic eyes. Ophthalmology 91:1045-1051, 1984

70. Heuer DK, Parrish RK, Gressel MG, et al: 5-fluorouraril and glaucoma filtering surgery. III. Intermediate follow-up of a pilot study. Ophthalmology 93:1537-1546, 1986

71. Heuer DK, Gressel MG, Parrish RK II, et al: Topical fluorouracil. II. Postoperative administration in an animal model of glaucoma filtering surgery. Arch Ophthalmol 104:132-136, 1986

72. Hilgers JHC: Strontium $90 \boldsymbol{\beta}$-irradiation, cataractogenicity and pterygium recurrence; results of a postirradiational survey five to six years after treatment. Arch Ophthalmol 76:329-333, 1966

73. Holm-Pederson P, Nilsson K, Branemark PI: The microvascular system of healing wounds in young and old rats. Adv Microcirc 5:80-106, 1973

74. Hoskins HD Jr, Hetherington J Jr, Shaffer RN: Surgical management of the inflammatory glaucomas. Perspect Ophthalmol $1: 173-181,1977$

75. Iliff CE: Surgical control of glaucoma in the Negro. $A m J$ Ophthalmol 27:731-738, 1944

76. Iliff CE, Haas JS: Posterior lip sclerectomy. Am J Ophthalmol 54:688-693, 1962

77. Inaba Z: Long-term results of trabeculectomy in the Japanese: an analysis by life-table method. Jpn J Ophthalmol 26:361-373, 1982

78. Jampel H, McGuigan L, Pepos JS, Quigley H: Biology of experimental glaucoma filtering surgery failure. Invest Ophthalmol Vis Sci (Suppl) 28:378, 1987

79. Jones IS, Reese AB: Focal scleral necrosis; a late sequel of irradiation. Arch Ophthalmol 49:633-636, 1953

80. Kapetansky FM: Trabeculectomy, or trabeculectomy plus tenectomy: a comparative study. Glaucoma 2:451-453, 1980

81. Kattan HM, Gaasteriand DE: Studies of formation of filtering tracts with laser contact surgery - enculeated eyes. ARVO Abstracts. Invest Ophthalmol Vis Sci (Suppl) 28:379, 1987

82. Kay JS, Litin BS, Jones MA, et al: Delivery of the antifibroblast agents as adjuncts to filtration surgery. Part II. Delivery of 5-fluorouracil and bleomycin in a collagen implant; pilot study in the rabbit. Ophthalmic Surg 17:796-801, 1986

83. Kietzman B: Glaucoma surgery in Nigerian eyes: a five-year study. Ophthalmic Surg 7(4):52-58, 1976

84. Knapp A, Heuer DK, Stern GA, Driebe WT Jr: Serious corneal complications of glaucoma filtering surgery with postoperative 5-fluorouracil. Am J Ophthalmol 103:183-187, 1987 
85. Kolker AE, Hetherington J Jr: Becker-Shaffer's Diagnosis and Therapy of the Glaucomas. St Louis, CV Mosby, 1983, pp 453-454

86. Ibid, p 509

87. Kornblueth $W$, Tenenbaum $E$ : The inhibitory effect of aqueous humor on the growth of cells in tissue cultures. $A m J$ Ophthalmol 42:70-74, 1956

88. Kronfeld PC: The chemical demonstration of transconjunctival passage of aqueous after antiglaucomatous operations. $A m$ J Ophthalmol 35:38-45, 1952

89. Kronfeld PC: The mechanism of filtering operations. Trans Pacific Coast Oto-Ophthalmol Soc 30:23-40, 1949

90. Krupin T, Kaufman P, Mandell AI, et al: Long-term results of valve implants in filtering surgery for eyes with neovascular glaucoma. Am J Ophthalmol 95:775-782, 1983

91. Kummell R: Uber das anatomische Verhalten der Narben nach Elliotscher Trepanation bei Kaninchen. Ber Ophthaimol ges 39:205-217, 1913

92. Kwong EM, Litin BS, Jones MA, Herschler J: Effect of antineoplastic drugs on fibroblast proliferation in rabbit aqueous humor. Ophthalmic Surg 15:847-851, 1984

93. Latina $M$, Goode S, de Kater AW, et al: Experimental abinterno sclerostomies using a pulsed dye laser. ARVO Abstracts. Invest Ophthalmol Vis Sci (Suppl) 28:379, 1987

94. Lee DA, Flores RA, Anderson PJ, Leong K: Filtration surgery in rabbits using slow release polymers and $5 \mathrm{FU}$. ARVO Abstracts. Invest Ophthalmol Vis Sci (Suppl) 27:212, 1986

95. Lee VHL, Urrea PT, Smith RE, Schanzlin DJ: Ocular drug bioavailability from topically applied liposomes. Surv Ophthalmol 29:335-348, 1985

96. Leibovich SJ, Ross R: The role of the macrophage in wound repair: a study with hydrocortisone and antimacrophage serum. Am J Pathol 78:71-100, 1975

97. Lemor M, de Bustros S, Glaser BM: Low-dose colchicine inhibits astrocyte, fibroblast, and retinal pigment epithelial cell migration and proliferation. Arch Ophthalmol 104:1223-1225, 1986

98. Lewis RA, Phelps GD: Trabeculectomy v thermosclerostomy; A five-year follow-up. Arch Ophthalmol 102:533-536, 1984

99. Litin BS, Kwong EM, Jones MA, Herschler J: Effect of antineoplastic drugs on cell proliferation - individually and in combination. Ophthalmic Surg 16:34-39, 1985

100. Loertscher H, Mandelbaum S, Parrish RK II, Parel J-M: Preliminary report on corneal incisions created by a hydrogen fluoride laser. Am J Ophthalmol 102:217-221, 1986

101. Luntz MH: Trabeculectomy using a fornix-based conjunctival flap and tightly sutured scleral flap. Ophthalmology 87:985-989, 1980

102. Mallick KS, Hajek AS, Parrish RK II: Fluorouracil (5-FU) and cytarabine (ara-C) inhibition of corneal epithelial cells and conjunctival fibroblast proliferation. Arch Ophthalmol 103: $1398-1402,1985$

103. March WF, Gherezghiher T, Koss MC, Nordquist RE: Experimental YAG sclerostomy. Arch Ophthalmol 102:1834-1836, 1984

104. March WF, Bernitsky D, Gherezghiher T, et al: Creation of filtering blebs with the YAG laser in primates and rabbits. Glaucoma 7:43-45, 1985

105. March WF, Gherezghiher T, Koss MC, et al: Histologic study of a neodymium-YAG laser sclerostomy. Arch Ophthalmol 103:860-863, 1985

106. Magrane WG: Canine Ophthalmology. Philadelphia, Lea and Febiger, 1977, ed 3, pp 163, 177

107. Martin CL, Anderson BG: Ocular anatomy, in Gclatt KN (ed): Textbook of Veterinary Ophthalmology. Philadelphia, Lea and Febiger, 1981, p 13

108. Maumenee AE: External filtering operations for glaucoma: The mechanism of function and failure. Trans Am Ophthalmol Soc 58:319-328, 1960

109. Maumenee AE: Mechanism of filtration of fistulizing glaucoma procedures. In: Symposium on Glaucoma; Transactions of the New Orleans Academy of Ophthalmology. St Louis, CV Mosby Co, 1981, pp 280-288

110. McBurney $M$ : The absence of cicatrization in the iris after operation or injury. Arch Ophthalmol 43:12-15, 1914

111. McGuigan LJB, Quigley HA, Young E, Lutty GA: Drug ef- fects on proliferation and collagen synthesis of conjunctival fibroblasts. ARVO Abstracts. Invest Ophthalmol Vis Sci (Suppl) $26: 125,1985$

112. McGuigan LJB, Cook DJ, Yablonski ME: Dexamethasone, Dpenicillamine, and glaucoma filtering surgery in rabbits. Invest Ophthalmol Vis Sci 27:1755-1757, 1986

112a. McGuigan LJB, Mason RP, Sanchez R, Quigley HA: Dpenicillamine and beta-aminopropionitrile effects on experimental filtering surgery. Invest Ophthalmol Vis Sci; in press

113. Mehta KR, Sathe SN, Karyekar SD: Trabeculectomy ab-externo. Indian J Ophthalmol 22(3):9-12, 1974

114. Melby JG: Systemic corticosteroid therapy: pharmacology and endocrinologic considerations. Ann Intern Med 81:505-512, 1974

115. Merritt JC: Filtering procedures in American blacks. Ophthalmic Surg 11:91-94, 1980

116. Miller B, Miller H, Ryan SJ: Experimental epiretinal proliferation induced by intravitreal red blood cells. Am J Ophthalmol 102:188-195, 1986

117. Miller MH, Joseph NH, Ennis KW, et al: An animal model of filtration surgery. Trans Ophthalmol Soc UK 104:893-897, 1985

118. Miller RD, Barber JC: Trabeculectomy in black patients. Oph thalmic Surg 12:46-50, 198

119. Mills KB: Trabeculectomy: a retrospective long-term followup of 444 cases. Br J Ophthalmol 65:790-795, 1981

120. Molteno ACB, Straughan JL, Ancker E: Control of bleb fibrosis after glaucoma surgery by anti-inflammatory agents. $S$ Afr Med J 50:881-885, 1976

121. Molteno ACB, Straughan JL, Ancker E: Long tube implants in the management of glaucoma. S Afr Med J 50:1062-1066, 1976

122. Molteno ACB, Van Rooyen MMB, Bartholomew RS: Implants for draining neovascular glaucoma. $\mathrm{Br} J$ Ophthalmol $61: 120-125,1977$

123. Molteno ACB, Van Bijon G, Ancker E: Two-stage insertion of glaucoma drainage implants. Trans Ophthalmol Soc NZ 31 $17-26,1979$

124. Molteno ACB: The use of draining implants in resistant cases of glaucoma; late results of 110 operations. Trans Ophthalmol Soc NZ 35:94-97, 1983

124a. Molteno ACB, Ancker E, Van Biljon G: Surgical technique for advanced juvenile glaucoma. Arch Ophthalmol 102:51-57, 1984

125. Moorhead LG: Inhibition of collagen cross-linking: a new approach to ocular scarring. Curr Eye Res 1:77-83, 1981

126. Moorhead LC: Effects of beta-aminopropionitrile after posterior penetrating injury in the rabbit. Am J Ophthalmol 95:97-109, 1983

127. Moorhead LC, Carroll J, Constance G, et al: Effects of topical treatment with B-aminopropionitrile after radial keratotomy in the rabbit. Arch Ophthalmol 102:304-307, 1984

128. Moorhead LG, Smith J, Stewart R, Kimbrough R: Effects of beta-aminopropiunitrile after glaucoma filtration surgery; pilot human study. Ann Ophthaimol 19:223-225, 1987

129. Nevarez JA, Parrish RK II, Heuer DK, et al: The effect of beta irradiation on monkey Tenon's capsule fibroblasts in tissue culture. Curr Eye Res 6:719-723, 1987

130. Parrillo.JE, Fauci AS: Mechanisms of glucocorticoid action on immune processes. Ann Rev Pharmacol Toxicol 19:179-201, 1979

131. Parrish R, Herschler J: Eyes with end-stage neovascular glaucoma; natural history following successful modified filtering operation. Arch Ophthalmol 101:745-746, 1983

132. Peacock EE Jr: Inflammation and the cellular response to injury, in Peacock EE Jr (ed): Wound Repair. Philadelphia, W B Saunders Co, 1984, pp 12-14

133. Peacock EE Jr: Biological and pharmacological control of scar tissue, in Peacock EE Jr (ed): Wound Repair. Philadelphia, W B Saunders Co, 1984, pp 491-492

134. Peacock EE Jr: Pharmacologic control of surface scarring in human beings. Ann Surg 193:592-597, 1981

135. Peacock EE Jr, Madden JW: Administration of beta-aminopropionitrile to human beings with urethral strictures; a preliminary report. Am I Surg 136:600-605, 1978

136. Pederson JE, Smith SG: Surgical management of encapsulated filtering blebs. Ophthalmology 92:955-958, 1985

137. Prince JH: Cornea, trabecular region, and sclera, in Prince JH 
(ed): The Rabbit in Eye Research. Springfield, IL, Charles C Thumas, 1964, pp 126-128

138. Prince JH, Eglitis I: The uvea (Choroid, ciliary body, and iris), in Prince JH (ed): The Rabbit in Eye Research. Springfield, IL, Charles C Thomas, 1964, p 148

139. Prince JH, Eglitis I: The crystalline lens, in Prince JH (ed): The Rabbit in Eye Research. Springfield, IL, Charles C. Thomas, 1964, pp 342, 351

140. Radius RL, Herschler J, Claflin A, Fiorentino G: Aqueous humor changes after experimental filtering surgery. $A m J$ Ophthalmol 89:250-254, 1980

141. Raymond CA: Liposomes embark on rescue mission to make highly toxic drugs more uscful. JAMA 257:1143-1144, 1987

142. Regan EF: Scleral cautery with iridectomy - an experimental study. Trans Am Ophthalmol Soc 61:219-231, 1963

143. Rich AM, McPherson SD: Trabeculectomy in the owl monkey. Ann Ophthalmol 5:1082-1088, 1973

144. Richter CU, Latina MA, Puliafito CA, Epstein DL: Excimer laser ablation of sclera. ARVO Abstracts. Invest Ophthalmol Vis Sci (Suppl) 27:254, 1986

145. Ridgway AEA, Rubinstein K, Smith VH: Trabeculectomy; a study of 86 cases. $\mathrm{Br} J$ Ophthalmol $56: 511-516,1972$

146. Ridgway AEA: Trabeculectomy; a follow-up study. $\mathrm{Br} J \mathrm{Oph}$ thalmol 58:680-686, 1974

147. Rivera AH, Hajek AS, Fantes F, et al: Trifluorothymidine and 5-fluorouracil: antiproliferative activity in tissue culture. Can J Ophthalmol 22:13-16, 1987

148. Rochon-Duvigneaud MM, Ducamp A: Recherches experimentales sur la cicatrisation des trepanations corneo-sclerales. Ann Oculist 150:45, 1913

149. Rockwood EJ, Parrish RK II, Heuer DK, et al: Glaucoma filtering surgery with 5-fluorouracil. Ophthalmology; 94:10711078, 1987

150. Ross R: Fibroblast proliferation induced by blood cells. Agents Actions (Suppl) 7:81-84, 1980

15I. Ross R, Raines EW, Bowen-Pope DF: The biology of plateletderived growth factor. Cell 46:155-169, 1986

151a. Ruderman SM, Welch DB, Smith MF, Shoch DE: A randomized study of 5-fluorouracil and filteration surgery. Am J Ophth almol 104:218-224, 1987

152. Ruskell GL: Blood vessels of the orbit and globe, in Prince JH (ed): The Rabbit in Eye Research. Springfield, IL, Charles C Thomas, 1964, pp 530-531

153. Sandford-Smith $\mathrm{JH}$ : The surgical treatment of open-angle glaucoma in Nigerians. Br J Ophthalmol 62:283-286, 1978

154. Schimek RA, Williamson WR: Trabeculectomy with cautery. Ophthalmic Surg 8(1):35-39, 1977

155. Schocket SS, Lakhanpal V, Richards RD: Anterior chamber tube shunt to an encircling band in the treatment of neovascular glaucoma. Ophthalmology 89:1188-1194, 1982

155a. Schocket SS, Nirankari VS, Lakhanpal V, et al: Anterior chamber tube shunt to an encircling band in the treatment of neovascular glaucoma and other refractory glaucomas; a longterm study. Ophthalmology 92:553-562, 1985

$155 \mathrm{~b}$. Schocket SS: Investigations of the reasons for success and failure in the anterior shunt-to-the-encircling-band procedure in the treatment of refractory glaucoma. Trans Am Ophthalmol Soc 84:743-798, 1986

156. Schwartz AL, Anderson DR: Trabecular surgery. Arch Ophthalmol 92:134-138, 1974

157. Schwartz PL, Ackerman J, Beards J, et al: Further experience with trabeculectomy. Ann Ophthalmol 8:207-217, 1976

158. Seetner A, Morin JD: Healing of trabeculectomies in rabbits. Can J Ophthalmol 14:121-125, 1979

159. Sharma SL, Singh T: Clinical evaluation of trabeculectomy operation in aphakic glaucoma. Indian J Ophthalmol 29. 227-228, 1981

160. Shields MB, Bradbury MJ, Shelburne JD, Bell SW: The permeability of the outer layers of limbus and anterior sclera. Invest Ophthalmol Vis Sci 16:866-869, 1977

161. Shields MB: Trabeculectomy vs full-thickness filtering operation for control of glaucoma. Ophthalmic Surg 11:498-505, 1980

162. Shields MB: Cholinergic stimulators, in Shields MB: Textbook of Glaucoma. Baltimore, Williams and Wilkins, 1987, p 381

163. Shuster JN, Krupin T, Kolker AE, Becker B: Limbus-v fornix based conjunctival flaps in trabeculectomy; a long-term, randomized study. Arch Ophthalmol 102:361-362, 1984

164. Simmons RJ: Filtering operations, in Epstein DL (ed): Chandler and Grant's Glaucoma. Philadelphia, Lea and Febiger, 1986, ed 3 , pp 421, 427, 447

165. Simmons ST, Sherwood MB, Nichols DA, et al: The pharmacokinetics of a 5-fluorouracil liposomal delivery system. $B r . J$ Ophthalmol; in press

166. Singh D, Singh M: Pretrabecular filtration in aphakic glaucoma. Indian $J$ Ophthalmol 26(1):17-21, 1978

167. Skuta GL, Assil K, Parrish RK II, et al: Filtering surgery in owl monkeys treated with the antimetabolite 5-fluorouridine $5^{\prime}$-monophosphate entrapped in multivesicular liposomes. $\mathrm{Am}$ J Ophthalmol 103:714-716, 1987

168. Smith TJ, Maurin MB, Milosovich SM, Hussain A: A membrane based sustained release ocular delivery system for 5 fluorouracil. ARVO Abstracts. Invest Ophthalmol Vis Sci (Suppl) $28: 271,1987$

169. Snell AC Jr: Wound healing of the iris. Am J Ophthalmol 41:499-505, 1956

170. Spaeth GL, Joseph NH, Fernandes E: Trabeculectomy: a reevaluation after three years and a comparison with Scheie's procedure. Trans Am Acad Ophthalmol Otolaryngol 79:349-361, 1975

171. Spaeth GL: A prospective, controlled study to compare the Scheie procedure with Watson's trabeculectomy. Ophthalmic Surg 11:688-694, 1980

172. Spaeth GL, Poryzees E: A comparison between peripheral iridectomy with thermal sclerostomy and trabeculectomy: a controlled study. $\mathrm{Br}$ J Ophthalmol 65:783-789, 1981

173. Spencer WH: Histologic evaluation of microsurgical glaucoma techniques. Trans Am Acad Ophthalmal Otolaryngal 76:389-397, 1972

174. Starita RJ, Fellman RL, Spaeth GL, et al: Short- and longterm effects of postoperative corticosteroids on trabeculectomy. Ophthalmology 92:938-945, 1985

175. Startup FG: Diseases of the Canine Eye. Williams and Wilkins Co, Baltimore, 1969, $\boldsymbol{\mu} 224$

176. Stewart RH, Kimbrough RL, Bachh H, Allbright M: Trabeculectomy and modifications of trabeculectomy. Ophthaimic Surg $10(1): 76-80,1979$

177. Sugar HS: Clinical effect of corticosteroids on conjunctival filtering blebs; a case report. Am / Ophthalmol 59:854-860, 1965

178. Sussman MD: Aging of connective tissue: physical properties of healing wounds in young and old rats. Am $J$ Physiol 224:1167-1171, 1973

179. Sutton GE, Popp JC, Records RE: Krupin-Denver valve and neovascular glaucoma. Trans Ophthalmol Soc UK 102:119-121, 1982

180. Talbot AN: Complications of beta ray treatment of pterygia. Trans Ophthalmol Soc NZ 31:62-63, 1979

181. Tarr KH, Constable IJ: Late complications of pterygium treatment. Br J Ophthalmol 64:496-505, 1980

182. Teng CC, Chi HH, Katzin HM: Histology and mechanism of filtering operations. Am J Ophthalmol 47:16-34, 1959

183. Thommy CP, Bhar IS: Trabeculectomy in Nigerian patients with open-angle glaucoma. $B r J$ Ophthalmol 63:636-642, 1979

183a. Traverso CE, Tomey KF, Antonios S: Limbal- vs. fornixbased conjunctival trabeculectomy flaps. Am J Ophthalmol 104:28-32, 1987

184. Uitto J: A method for studying collagen biosynthesis in human skin biopsies in vitro. Biochim Biophys Acta 201:438-445, 1970

185. Van Buskirk EM: Cysts of Tenon's capsule following filtration surgery. Am J Ophthalmol 94:522-527, 1982

186. Verdoorn C, Miller B, Miller H, et al: The role of growth factors in proliferative vitreoretinopathy. ARVO Abstracts. Invest Ophthalmol Vis Sci (Suppl) 26:23, 1985

187. Wadsworth JAC: Corneoscleral cautery; pathology and technique. Arch Ophthalmol 94:633-636, 1976

188. Watson PG, Grierson I: The place of trabeculectomy in the treatment of glaucoma. Ophthalmology 88:175-196, 1981

189. Watkins PH Jr, Brubaker RF: Comparison of partial-thickness and full-thickness filtration procedures in open-angle glaucoma. Am J Ophthalmol 86:756-761, 1978

189a. Weinreb RN: Adjusting the dose of 5-fluorouracil after filtera- 
tion surgery to minimize side effects. Ophthalmology 94:564570,1987

190. Welsh NH: Failure of filtration operations in the African. $B r J$ Ophthalmol 54:594-598, 1970

191. Welsh NH: Trabeculectomy with fistula formation in the African. Br J Ophthalmol 56:32-36, 1972

192. White A, Handler P, Smith EL: Principles of Biochemistry. New York, McGraw-Hill Book Co, 1978, pp 1139-1141

193. Wiedemann $P$, Ryan SJ, Novak $P$, Sorgente $N$ : Vitreous stimulates proliferation of fibroblasts and retinal pigment epithelial cells. Exp Eye Res 41:619-628, 1985

194. Wilmer WH: Discussion on the results of the operative treatment of glaucoma. Trans Ophthalmol Soc UK 47:230-293, 1927

194a. Wilson MR, Reaves H: Additional comments on the effects of triamcinolone injection (letter). Arch Ophthalmol 105:1166, 1987

195. Winter DF, Jones MA, Simmons ST, Smith RS: A histologic analysis of a 5-fluorouracil liposomal delivery system following subconjunctival injection in rabbits. ARVO Abstacts. Invest Ophthalmol Vis Sci (Suppl) 28:271, 1987

196. Woods AC: Clinical and experimental observation on the use of ACTH and cortisone in ocular inflammatory disease. $A m J$ Ophthalmol 33:1325-1349, 1950

197. Yeo JH, Sadeghi J, Campochiaro PA, et al: Intravitreous fibronectin and platelet-derived growth factor; new model for traction retinal detachment. Arch Ophthalmol 104:41 7-421, 1986

\section{Outline}

I. Clinical and histopathologic findings after glaucoma filtering surgery

A. Bleb formation, failure, and encapsulation

B. Histopathologic findings

C. Aqueous pathways

II. Animal models of glaucoma filtering surgery
A. Rabbits
B. Dogs and cats
C. Monkeys

III. Sequence of events in wound healing

IV. Anatomical and physiological factors related to bleb failure
A. External factors
B. Intraocular and scleral factors
C. Inflammation and blood

V. Clinical factors associated with bleb failure A. Youth
B. Aphakia
C. Anterior segment neovascularization
D. Previously failed glaucoma filtering surgery
E. Race

VI. Aqueous humor effects that may enhance bleb formation

A. Direct effects

B. Effects on fibroblasts

VII. Clinical factors that may enhance bleb formation

A. Surgical technique

1. Preoperative, intraoperative, and postoperative care

2. Full-thickness versus partial-thickness procedures

3. Excision of Tenon's capsule

4. Fornix versus limbus-based flap

5. Beta radiation

6. Implants in glaucoma filtering surgery

B. Pharmacologic modulation of wound healing

1. Corticosteroids

2. Antimetabolites

3. Inhibitors of collagen cross-linking

VIII. Future directions
A. More effective drug delivery
1. Liposomes
2. Polymers and membranes
3. Combination drug therapy
B. Surgical innovation
C. Better understanding of wound healing

IX. Conclusions

This review was supported in part (Dr. Skuta) by Public Health Service Research Training Grant 2T32EY07021, Department of Health and Human Services, National Institutes of Health, National Eye Institute, Bethesda, Maryland 20205.

Dr. Skuta is now with the W.K. Kellogg Eye Center, Department of Ophthalmology, Univcrsity of Michigan Medical School, Ann Arbor, Michigan.

Reprint requests should be addressed to Gregory Skuta, M.D., W.K. Kellogg Eye Center, 1000 Wall St, Ann Arbor, MI 48105. 